NASA Technical Memorandum 87251

NASA-TM-87251 19860022257

\title{
Correlation of Processing and Sintering Variables With the Strength and Radiography of Silicon Nitride
}

William A. Sanders and George Y. Baaklini Lewis Research Center Cleveland, Ohio

\section{FOR RERERENCE}

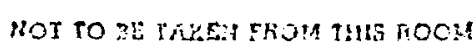

February 1986

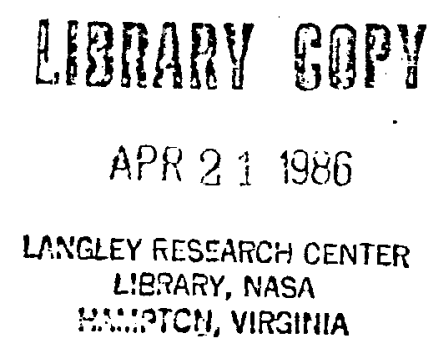

N/SN 


\title{
CORRELATION OF PROCESSING AND SINTERING VARIABLES WITH
}

\section{THE STRENGTH AND RADIOGRAPHY OF SILICON NITRIDE*}

\author{
William A. Sanders \\ National Aeronautics and Space Administration \\ Lewis Research Center \\ Cleveland, Oh10 44735 \\ and \\ George $Y$. Baaklini \\ Cleveland State University \\ Cleveland, Ohio
}

\section{SUMMARY}

A sintered $\mathrm{Si}_{3} \mathrm{~N}_{4}-\mathrm{SiO}_{2}-\mathrm{Y}_{2} \mathrm{O}_{3}$ composition, NASA $6 Y$, was developed that reached four-point flexural average strength/standard deviation values of $857 / 36,544 / 33$, and $462 / 59 \mathrm{MPa}$ at room temperature, 1200 and $1370{ }^{\circ} \mathrm{C}$ respectively. These strengths represented improvements of 56,38 , and 21 percent over baseline properties at the three test temperatures. At room temperature the standard deviation was reduced by over a factor of three. These accom. plishments were realized by the iterative utilization of conventional $x$-radiography to characterize structural (density) uniformity as affected by systematic changes in powder processing and sintering parameters. Accompanying the improvement in mechanical properties was a change in the type of flaw causing fallure from a pore to a large columnar $\mathrm{B}-\mathrm{Si}_{3} \mathrm{~N}_{4}$ grain typically 40 to. $80 \mu \mathrm{m}$ long, 10 to $30 \mu \mathrm{m}$ wide, and with an aspect ratio of $5: 1$.

\section{INTRODUCTION}

Silicon nitride is a prime candidate for heat engine applications based upon oxidation resistance, thermal shock resistance and room and elevated temperature strength. However, scatter in mechanical properties is a great draw. back from a design/reliability standpoint. This scatter is attributed to defects and inhomogeneities occurring during processing of $\mathrm{Si}_{3} \mathrm{~N}_{4}$ powder compo. sitions, and/or during fabrication of silicon nitride parts (refs. 1 to 3 ). In recent work at NASA Lewis, Klima (ref. 4) described density gradients in sintered $\mathrm{Si}_{3} \mathrm{~N}_{4}$ found by conventional x-ray radiography. From this preliminary work, it was not possible to draw firm conclusions, but it was evident that density gradients were strongly dependent upon sintering conditions. In other unpublished work at Lewis, $x$-ray radiography also revealed density gradients in two commercial sintered $\mathrm{Si}_{3} \mathrm{~N}_{4}$ materials.

Based upon the sintered $\mathrm{Si}_{3} \mathrm{~N}_{4}$ preliminary $x$-radiographic characterization work at NASA Lewis (ref. 4), a program was undertaken to systematically inves. tigate density gradient-flexural strength relationships as affected by sinter.

${ }^{*} A$ shortened version of this report was presented at Tenth Annual Conference on Composites and Advanced Ceramic Materials, sponsored by the American Ceramic Society, Cocoa Beach, Florida, January 19-24, 1986. 
ing and powder processing variables for sintered $\mathrm{Si}_{3} \mathrm{~N}_{4}$. The sintering variables were temperature, nitrogen overpressure, time, setter contact, and furnace position. The powder processing variables were grinding time, and inclusion or exclusion of powder wet sieveing procedures.

This paper describes the results of an extensive investigation of one $\mathrm{Si}_{3} \mathrm{~N}_{4}-\mathrm{SiO}_{2}-\mathrm{Y}_{2} \mathrm{O}_{3}$ composition involving sintering trials of 27 batches of material. Sintering/processing conditions were varied based on feedback from radiography to obtain high density uniform structures with concomitant improved strength and reduced scatter. Radiographic, light microscope, and transmission electron microscope results are discussed and related to sintering and proces. sing variables. Room temperature, 1200 and $1370{ }^{\circ} \mathrm{C}$ flexural strength, and SEM fractography results are discussed and examples of critical flaw types are presented. A new flaw type, a large columnar grain has become dominant at all three test temperatures as a result of process improvements.

\section{Experimental Procedure}

Materials. - $\mathrm{Si}_{3} \mathrm{~N}_{4}, \mathrm{SiO}_{2}$ and $\mathrm{Y}_{2} \mathrm{O}_{3}$ powders were processed according to the flow chart of figure 1. This processing was similar to that employed for the $\mathrm{Si}_{3} \mathrm{~N}_{4}-\mathrm{SiO}_{2}-\mathrm{Y}_{2} \mathrm{O}_{3}$ composition, designated NASA $6 Y$, in a NASA Lewis project to establish an in-house baseline for sintered $\mathrm{Si}_{3} \mathrm{~N}_{4}$ ( ref. 5). The powders were ground together as $100 \mathrm{~g}$ charges in 1 liter RBSN mills 1 filled with HPSN media.2 The media charges were $800 \mathrm{~g}$ of $1 \mathrm{~cm}$ by $1 \mathrm{~cm}$ HPSN cylinders and the grinding fluid was $1 / 2$ liter of pure ethanol. Grinding times $\left(t_{g}\right)$ were 24 , 100 , or $300 \mathrm{hr}$. After milling, the powder-ethanol slurries were transferred to a drying apparatus employing a heated water bath and a vacuum connection for removal of ethanol vapor. 3 Powders were further dried in a vacuum oven at $110^{\circ} \mathrm{C}$. The softly agglomerated powders were then manually crushed using HPSN hardware and sieved through a $149 \mu \mathrm{m}$ screen. These powders were then die pressed into bars at $21 \mathrm{MPa}$ using a double-acting tungsten carbide-lined die. The die-pressed bars measured 3.81 by 0.79 by $0.45 \mathrm{~cm}$ and weighed $2.6 \mathrm{~g}$ each. These bars were then vacuum sealed in thin-wall latex tubing and isostatically cold pressed at $414 \mathrm{MPa}$. The dotted boxes in figure 1 refer to departures from the standard powder processing procedure involving 20 and $10 \mu \mathrm{m}$ wet sieveing to minimize large particles or agglomerates. The green density range for 23 separate batches of NASA $6 Y$ was 1.86 to $1.92 \mathrm{~g} / \mathrm{cm}^{3}, 59$ to 61 percent of the calculated theoretical density 4 of $3.16 \mathrm{~g} / \mathrm{cm}^{3}$.

${ }^{1}$ Ceramic Systems Incorporated, Detroit, MI-Chemical analysis of the mill indicate: 0.04 percent $C, 2$ percent 0,3 percent $\mathrm{Fe}$, and expressed in parts per million: $3600 \mathrm{Al}, 710 \mathrm{Ca}, 410 \mathrm{Cr}, 500 \mathrm{Cu}, 350 \mathrm{Mg}, 310 \mathrm{Mn}, 70 \mathrm{Ni}, 250 \mathrm{Ti}$, and $110 \mathrm{~V}$.

2 Advanced Ceramic Systems, Ypsilanti, MI-Chemical analysis of the media indicate: 5.25 percent $0,0.46$ percent $C, 0.8$ percent $A 1$, and, expressed in parts per million: $670 \mathrm{Ca}, 30 \mathrm{Cu}, 2000 \mathrm{Fe}, 2 \mathrm{Ti}, 370 \mathrm{Cr}, 130 \mathrm{Mg}, 90 \mathrm{Mr}$, $<10 \mathrm{~V},<20 \mathrm{Zr}, 2000 \mathrm{Mo}, 240 \mathrm{Ni}, 130 \mathrm{Zn},<30 \mathrm{~Pb},<60 \mathrm{Sn}$.

3 Rotavapor, Prieser Scientific, Louisville, Kentucky.

4 Theoretical density was calculated by the law of mixtures for the compounds $\mathrm{Si}_{3} \mathrm{~N}_{4}, \mathrm{SiO}_{2}$ and $\mathrm{Y}_{2} \mathrm{O}_{3}$. 
Table I gives the chemical analyses of the starting powders and summarizes the charge weight percentages for each $6 Y$ batch before grinding. Charge weights of $\mathrm{Si}_{3} \mathrm{~N}_{4}, \mathrm{SiO}_{2}$, and $\mathrm{Y}_{2} \mathrm{O}_{3}$ were specific to each of the three grinding times of 24,100 , and $300 \mathrm{hr}$ to allow for $\mathrm{Si}_{3} \mathrm{~N}_{4}$ oxidation and $\mathrm{Si}_{3} \mathrm{~N}_{4} \mathrm{milling}$ hardware wear so as to arrive at close to the same composition for each $6 Y$ batch. One $200-g$ batch $6 Y-29$, was prepared. Table I also gives the specific surface areas, carbon analyses, and trace element analyses after milling. The specific surface areas were determined by the 3-point BET method, and averaged $15.4,23.0$, and $38.2 \mathrm{~m}^{2} / \mathrm{g}$ for the 24,100 , and $300 \mathrm{hr}$ grinding times, respectiveiy. Oxidation occurs during miliing as evidenced by an increase in the oxygen content. $\mathrm{Si}_{3} \mathrm{~N}_{4}$ pickup from wear of the $\mathrm{Si}_{3} \mathrm{~N}_{4}$ milling hardware averaged $3.3,5.6$, and $7.3 \mathrm{~g}$ for 24,100 , and $300 \mathrm{hr}$ grinding times respectively. The average calculated phase contents in the sintered condition in mole percent for the 23 separate batches of $6 Y$ were $83.9,12.4$, and 3.7 for $\mathrm{Si}_{3} \mathrm{~N}_{4}, \mathrm{SiO}_{2}$, and $\mathrm{Y}_{2} \mathrm{O}_{3}$, respectively. In table I the batch referred to as Baseline was made up of five separate batches. Phase content calculations were based on initial charge composition, $\mathrm{Si}_{3} \mathrm{~N}_{4}$ pickup from the milling hardware, oxygen analyses after milling and reduction of some $\mathrm{SiO}_{2}$ by carbon assumed to occur during sintering.

Weighed and measured bars were sintered 15 at a time in a $6.6 \mathrm{~cm}$ diameter by $6.6 \mathrm{~cm} \mathrm{high} \mathrm{tungsten} \mathrm{cup} \mathrm{with} \mathrm{a} \mathrm{loose-fitting} \mathrm{lid} \mathrm{in} \mathrm{a} \mathrm{water} \mathrm{cooled} \mathrm{double.}$ wall furnace. As shown in figure 2, bars were stacked in 5 layers, a layer consisting of 3 bars in a triangular array so that each bar in a layer had a position equivalent to its 2 neighbors. The bars rested on their narrow faces to a greater (Max BN Contact) or lesser (Min BN Contact) extent on 2.5 or $1.3 \mathrm{~cm}$ diameter high-purity $B N$ disc setters which separated the bars from one another and from contact with the tungsten cup. The loaded tungsten cup was placed on a tungsten pedestal centered within a $10.2 \mathrm{~cm}$ diameter tungsten mesh heater. Surrounding the heater were concentric $W$ and Mo radiation shields. sintering temperatures $(T)$ were monitored and controlled with W-5Re/W-26Re thermocouples. All batches were sintered at $2140{ }^{\circ} \mathrm{C}$ with the exception of one $6 Y$ batch, $6 Y-21$, which was sintered at $2050{ }^{\circ} \mathrm{C}$. Sintering times $\left(t_{s}\right)$ were $1,1.25,1.5$ and $2 \mathrm{hr}$. Heating from R.T. to $2140^{\circ} \mathrm{C}$ was at an approximately linear rate and took 45 minutes. Nitrogen overpressures of $2.5,3.5$, and 5.0 MPa were employed. For each $6 Y$ batch number with associated milling time, table II lists the conditions of sintering and the sintering results.

The bars were weighed and measured before and after sintering to determine weight loss and shrinkage. The bars were longitudinally ground with a 400 grit diamond wheel and the four long edges were beveled $0.12 \mathrm{~mm}$. Surface finish measured 6 and $15 \mu$-in in the longitudinal and transverse directions, respec. tively. Final test bar dimensions were 3.0 by 0.56 by $0.28 \mathrm{~cm}$.

\section{X-Ray Radiographic Techniques}

X-radiography, (refs. 6 and 7), using conventional equipment, was operated in the 25- to 75-kV range with a beam current range of 5 to $8 \mathrm{~mA}$. The $x$-ray system (fig. 3) had a tungsten anode and a $700 \mu \mathrm{m}$ focal spot size. Test bars were positioned $92 \mathrm{~cm}$ away from the source of radiation and in direct contact with the $x$-ray film. The exposure time varied from 5 to 12 min, depending on other exposure parameters, in order to produce a flim density range of 1.5 to 2.5. All radiographs were manually developed. To obtain uniform results, extra care was taken to eliminate film artifacts, maintain chemical concentra. tions, and control solution temperature and processing times. Radiographs were 
examined with the aid of a $\times 7$ measuring magnifier under variable intensity backlighting $\left(1000\right.$ to $\left.90001 \mathrm{u} / \mathrm{m}^{2}\right)$, and in subdued room lighting. In general, $x 2$ black and white prints were made for inter-batch comparisons. Test bars were radiographed in two modes, 1) the $(W, L)$ mode where $x$-rays are transmitted through the thickness of the bar forming a two-dimensional image on the film detector, and 2$)$ the $(T, L)$ mode where $x$-rays are transmitted through the width of the bar forming a two-dimensional image on the film detector. These two modes ( $f i g .3)$ combined offer a three-dimensional radiographic presentation of the test bars. Further, the (T,L) mode highlights the tensile side radiographic evaluation which is of primary interest in four-point bending. All batches were radiographically evaluated at all stages of fabrication as described in the characterization-testing-evaluation flow chart (fig. 4).

\section{Testing and Analysis}

Four-point flexural strength tests were conducted at a crosshead speed of $0.51 \mathrm{~mm} / \mathrm{min}$ with inner and outer spans of 9.53 and $19.05 \mathrm{~mm}$ respectively. Room temperature tests were conducted with steel fixtures. Elevated temperature tests were conducted using SiC fixtures in a SiC muffle furnace mounted on a testing machine. 5 All tests were conducted in air. Fracture surfaces were examined in a scanning electron microscope (SEM).

$X$-ray diffractometer scans of ground surfaces of NASA $6 Y \mathrm{Si}_{3} \mathrm{~N}_{4}$ test bars showed $\mathrm{B}-\mathrm{Si}_{3} \mathrm{~N}_{4}$ to be the only detectable crystalline phase.

For microstructural characterization, polished cross sections of test bars were examined by light microscopy, and electron probe microanalys is. In the electron probe, concentrations of nitrogen, oxygen, yttrium, and boron were traced from the center of each cross section to the edges of the cross section. Transmission electron microscopy (TEM) was accomplished utilizing two-stage carbon replicas made from polished and etched cross sections. Etching involved immersion in fused $\mathrm{KOH}$ for approximately $45 \mathrm{sec}$.

\section{Results}

This study involves the evaluation of 21 batches of sintered $\mathrm{Si}_{3} \mathrm{~N}_{4}$ (NASA 6Y) as listed in table II along with sintering results such as weight loss, shrinkage, and machined density. Two green bar batches, 24 and 26 , were divided into halves $A$ and $B$ which received different sintering treatments. All batches were compared with Baseline $6 Y$ also listed. The processing and sintering conditions listed in table II were selected based upon the $x$-ray radiographic results of previous sinter trials (fig. 4). The goal was to increase density and to minimize density gradients within bars and from bar to bar. Attainment of this goal would be expected to improve strength and reduce scatter.

Structural characterization results are presented in table III which is a summary of TEM work on selected 6Y batches. Table III lists grain size ranges, columnar grain aspect ratios, and volume percents of columnar grains. Figure 5

5 Instron Corporation, Canton, Massachusetts. 
shows radiographs of green isopressed NASA $6 Y \mathrm{Si}_{3} \mathrm{~N}_{4}$. Figures 6 through 9 consist of radiographs and light macrographs and micrographs of sintered test bars illustrating the sensitivity of radiography to within-bar density differences and to processing/sintering changes resulting in improved structural uniformity. The improved structure of batch $316 \mathrm{Y} \mathrm{Si}_{3} \mathrm{~N}_{4}$ is compared to the structure of Baseline material (figs. 8 and 9). The TEM micrographs in figures 10 through 12 illustrate case and core microstructures and microstructures as they vary with sinter temperature and powder grinding time.

Flexural test results at room temperature, 1200 and $1370{ }^{\circ} \mathrm{C}$ are tabulated in table IV and presented in bar chart comparisons as a function of $t_{g}, t_{s}$, $T$, BN setter contact, sinter height combined with wet sieveing, and modified processing/sintering procedures. Bar chart comparisons in figures 13 to 15 show the flexural strength improvements realized by increasing sinter time, grinding time, and sintering temperature respectively. Figure 16 shows the room temperature strength benefit to be gained by minimizing BN setter contact with test bars during sintering. Room temperature strength improvement was also demonstrated in figure 17 as a result of a sinter height adjustment. Figure 18 is a summary bar chart illustrating the continually improving strength at all test temperatures as a result of successive improvements in processing/sintering procedures.

Results of a fractographic study of all bars fractured at room tempera. ture, 1200 and $1370{ }^{\circ} \mathrm{C}$ are summarized in tables V, VI, and VII respectively. Fractographs of the most frequently found critical flaws are presented in fig. ures 19 and 20. The fractographs comprising figures 21 through 25 present a large columnar grain flaw type found to dominate fracture at all three test temperatures for the most improved batch of sintered $\mathrm{Si}_{3} \mathrm{~N}_{4}$, batch 31 .

\section{Discussion}

Sintering. - Averages for percent weight loss and percent width shrinkage and for machined density are given in table II. In regards to weight loss, it was noted that increases in sintering temperature (batch 21 versus batches 17 and 20), and powder grinding time (Baseline batch versus batch 11 versus batch 12) resulted in increased weight loss. This result would be expected regarding the temperature variable, and is likely related to increased surface area for the powder grinding time variable. As would be expected, increased overpressures of $n i t r o g e n$ resulted in decreases in weight loss (batch 13 versus batch 26A versus batch 26B) by virtue of suppression of the decomposition of $\mathrm{Si}_{3} \mathrm{~N}_{4}$. No other weight loss trends were noted.

Width shrinkage averages were all above 16 percent except for Baseline batch (15.6 percent) and batch 21 ( 14.9 percent). The former had no processing or sintering modifications, and the latter was sintered at $2050{ }^{\circ} \mathrm{C}$ instead of the standard sintering temperature of $2140{ }^{\circ} \mathrm{C}$. Baseline batch and batch 21 had correspondingly low machined densities of 3.12 and $3.05 \mathrm{~g} / \mathrm{cm}^{3}$. All other batches had densities which overall averaged $3.23 \mathrm{~g} / \mathrm{cm}^{3}$. These densities exceed the calculated theoretical density of $3.16 \mathrm{~g} / \mathrm{cm}^{3}$ previousiy given. This calculation assumed for simplicity that the three compounds $\mathrm{Si}_{3} \mathrm{~N}_{4}, \mathrm{SiO}_{2}$ and $\mathrm{Y}_{2} \mathrm{O}_{3}$ were present. In actuality, the only crystalline phase observed after sintering was $\mathrm{B}-\mathrm{Si}_{3} \mathrm{~N}_{4}$, the $\mathrm{SiO}_{2}$ and $\mathrm{Y}_{2} \mathrm{O}_{3}$ additives being present in an amorphous oxynitride glass phase of unknown density. Based upon post-sinter oxygen anal. yses, observed sinter weight losses and measured densities, it is estimated 
that the oxynitride glass phase in NASA $6 Y$ sintered $\mathrm{Si}_{3} \mathrm{~N}_{4}$ has a density of approximately $3.6 \mathrm{~g} / \mathrm{cm}^{3}$ for a typical sintered $\mathrm{St}_{3} \mathrm{~N}_{4}$ bar density of $3.23 \mathrm{~g} / \mathrm{cm}^{3}$.

\section{Structure}

The use of $x$-radiography as depicted schematically in figure 3 , and complemented by light and transmission electron microscopy, was found to be very beneficial in judging the merit of powder processing and sintering parameter adjustments made to improve the density and uniformity of sintered $\mathrm{Si}_{3} \mathrm{~N}_{4}$. The radiographs in figure 3 show $(W, L)$ and $(T, L)$ views of a Baseline $\mathrm{Si}_{3} \mathrm{~N}_{4}$ bar which has the dense, nonuniform case/less dense, nonuniform core structure. This structure does not show up in green bar radiography ( $f i g .5$ ), however density/thickness nonuniformities are indicated by the overall darkness/ lightness of the bars. Also, high density inclusions (dark specks) and low density inclusions or voids (light specks) are apparent. High density inclusions noted in the green state have been found to be rich in $\mathrm{Fe}$, Sn, and $\mathrm{Ni}$-base alloy ( $\mathrm{Ni}, \mathrm{Cr}, \mathrm{Co}, \mathrm{Ti})$ (ref. 4). Metal oxide sintering aid additive agglomerates have also been revealed in green bars.

Further discussion on structure will consist first of a brief summary describing efforts to eradicate the case-core structure followed by figures illustrating the success of our efforts.

The case-core phenomenon for sintered $\mathrm{Si}_{3} \mathrm{~N}_{4}$ with $\mathrm{Y}_{2} \mathrm{O}_{3}$ and $\mathrm{SiO}_{2}$ additions was first noted when radiographs were taken through the width-length planes $(W, L)$ of Baseline $\mathrm{Si}_{3} \mathrm{~N}_{4}$ bars sintered under $2.5 \mathrm{MPa}$ nitrogen pressure which had been supported on the thickness-length $(T, L)$ planes by $2.5 \mathrm{~cm}$ BN discs (fig. 2). The core of such a bar was found to be 3 percent less dense than the bar as a whole (ref. 8). The case-core structure was examined as a function of powder fineness (milling time) and the sintering variables, time, sinter height, nitrogen overpressure, and degrec of BN contact. Based on radiography, it was observed that increased powder fineness resulting from 100 or $300 \mathrm{hr}$ milling times in comparison to a $24 \mathrm{hr}$ milling time resulted in thinner, less distinct cases. Also, minimizing the BN setter contact by using $1.27 \mathrm{~cm} \mathrm{BN}$ discs instead of $2.54 \mathrm{~cm} B N$ discs resulted in more uniform case thickness. But increasing nitrogen overpressure from 2.5 to 3.5 or $5.0 \mathrm{MPa}$ had no effect on the case-core structure. Employing then, a $100 \mathrm{hr}$ milling time, the smaller BN discs, and a nitrogen overpressure of $5.0 \mathrm{MPa}$, it was found that increasing sinter time from 1 to $2 \mathrm{hr}$, and raising the height of the sinter cup $3.8 \mathrm{~cm}$ was very effective in greatly reducing density gradients in sintered bars and in eliminating top to bottom bar density differences. It is estimated that raising the sinter cup height raised the sintering temperature of the bottom 6 bars by approximately $25^{\circ} \mathrm{C}$.

The sensitivity of radiography to within bar porosity segregation and distribution is shown in figure 6 for $6 Y \mathrm{Si}_{3} \mathrm{~N}_{4}$ batch 23 . The $(T, L)$ radio. graph (fig. 6(a)) shows dense case (dark) at the top and bottom and two regions of lower density (light) within, but separated by a central dense region (dark). This structure is substantiated in the light photomacrograph of figure $6(b)$ of a polished cross section of a test bar wherein the regions of different density are apparent. The light micrograph, part (c) of figure 6 , details the nature of the dense case at the bar top, essentially pore-free, in comparison to coarse porosity and fine porosity of the internal porous zones. 
Figure 7 illustrates the benefit of radiography in judging if bars sintered together in the same 15-bar sinter run have the same structure. Figure $7(b)$ shows the nonuniformity of particularly the bottom six bars in comparison to the top nine bars of $6 Y \mathrm{Si}_{3} \mathrm{~N}_{4}$ batch 23. As previously shown in figure 2, bars are sintered in layers of three, stacked five high. By raising the sinter cup height $3.8 \mathrm{~cm}$, the structures of bars top to bottom became much more uniform as shown in figure $7(\mathrm{~A})$ for batch 28 bars. The uniformity of batch 28 showed up in higher R.T. flexure strength, $672 \mathrm{MPa}$, and lower standard deviation, $74 \mathrm{MPa}$ than for batch 23 where flexure strength was less at $632 \mathrm{MPa}$ and the standard deviation was much greater at $168 \mathrm{MPa}$.

Figures 8 and 9 compare the $6 \mathrm{Y} \mathrm{Si}_{3} \mathrm{~N}_{4}$ baseline batch compared to the most improved batch, number 31 . Figure 8 illustrates the sensitivity of radiography to slight density variation, that is, the case-core structure in $8(A)$ for the baseline batch; also illustrated is the radiographic uniformity for the most improved batch, number 31 . Microstructures for the two batches are also compared and related to position in the bar by reference to the radiographs. The top and bottom surfaces, (W, L) planes of most improved batch 31 have essentially pore-free zones of equal thickness. However, the top and bottom surfaces ( $W, L)$ planes of baseline batch contain fine porosity zones of dissimilar thickness and appearance. Also, it can be noted that the internal porosity of most improved batch 31 is considerabiy less than that of the baseline batch. Figure 9 further compares case and core regions for the baseline batch (A) and batch 31 (B) materials showing the porosity distributions between case and core within each sample and between the two samples. The macrograph in figure 9(a) shows a large central core region of lower density than the case with the accompanying microstructures detalling the porosity differences. For improved batch $316 \mathrm{~S} \mathrm{Si}_{3} \mathrm{~N}_{4}$, the macrograph in figure 9 (b) shows a dense, pore-free case and a core with patches of porosity less severe than the porous core of the baseline material. Thus, as previously stated, the improved structure for batch 31 can be attributed to:

(1) increased powder fineness (resulting from 100 and $300 \mathrm{hr}$ milling times) improving sinterability and uniformity

(2) minimizing $B N$ setter contact resulting in more uniform densification as a consequence of more uniform heating

(3) increased sintering time from 1 to $2 \mathrm{hr}$ for improved density and uniformity

(4) raising sinter cup height for reduction of top bar to bottom bar temperature gradient for bar to bar uniformity.

Although radiography was applied successfully to control and optimize processing and sintering, it was not intended at this stage to locate the critical flaws which were identified in the SEM and presented in tables $V$ to VII. The radiographic procedures used precluded definition of critical flaws for the following reasons:

(1) The current radiographic exposures were taken to highlight the density gradients present within and among the test bars. And the presence of the density gradients actually masked minute and detailed information about the presence of fracture causing flaws. 
(2) Different exposures at different voltage levels, currents, and times would have been needed in order to radiographically detect different types of flaws.

(3) Projection microfocus radiography (refs. 9 and 10) would have to be used where increased sensitivity is required as is the case when detecting surface and subsurface discrete voids.

(4) Test bars would have to be radiographed using several orientations relative to the $x$-ray beam direction in order to have the plane of some critical flaws e.g., seams ( $f$ ig. 20) aligned with the direction of the $x$-ray beam.

To satisfy most of the requirements listed above would have been not only very time consuming but also not sufficient to identify most critical flaws. In fact, other NDE techniques e.g., scanning acoustic microscopy, scanning laser acoustic microscopy, and high frequency ultrasonics would be needed to complement radiography in detecting critically sized defects that cause fracture in machined test bars.

Some grain size and morphology comparisons are presented in the transmis. sion electron micrographs of figures 10 to 12 . Figure 10 compares case and core structures for $6 \mathrm{Y} \mathrm{Si}_{3} \mathrm{~N}_{4}$ batch 23 , ground $100 \mathrm{hr}$ and then sintered for $1.25 \mathrm{hr}$ at $2140{ }^{\circ} \mathrm{C}$ under $5.0 \mathrm{MPa}$ nitrogen pressure. The case contained a higher columnar grain content than the core, estimated at 50 vol \% versus 20 vol \%. This is thought to reflect more complete sintering for the case than for the core. Columnar grain width and aspect ratio ranges were very similar. However, the equiax grain size in the core 0.2 to $5.0 \mu \mathrm{m}$ was larger than in the case, 0.2 to $3.0 \mu \mathrm{m}$. The effects of temperature and grinding time for $2 \mathrm{hr}$ sinter time on grain size and morphology are illustrated in figure 11. The $2140{ }^{\circ} \mathrm{C}$ sinter temperature for batch 20 yields a more fully sintered and denser structure (B) of larger equiax and columnar grains than the $2050{ }^{\circ} \mathrm{C}$ sinter temperature for batch 21 structure (A) and a greater quantity of colum. nar grains, 50 versus 30 vol \%. The grinding time effect is interesting in that the coarseness of the starting powder, determined by the grinding time, is carried over to the sintered product. Thus the coarser $24 \mathrm{hr}$ ground powder, batch 16 (BEI $\left.15.1 \mathrm{~m}^{2} / \mathrm{g}\right)$, sintered at $2140{ }^{\circ} \mathrm{C}$, yielded greater equiax and columnar grain sizes (C) than the finer batch 20 powder (BET $21.2 \mathrm{~m}^{2} / \mathrm{g}$ ) which was ground for $100 \mathrm{hr}$ (B). This same grinding time effect on microstructure was also found for batches Baseline, 13, and 14 which were ground for 24, 100, and $300 \mathrm{hr}$ respectively (fig. 12). Specific surface areas were 15.3, 24.9, and $37.2 \mathrm{~m}^{2} / \mathrm{g}$ for the 24,100 , and $300 \mathrm{hr}$ grinding times. In addition to the $24 \mathrm{hr}$ ground baseline batch having the largest equiax and columnar grain size, it also had the highest volume percent of columnar grains, 70 percent.

Electron probe microanalyzer traces were made on polished cross sections of test bar halves representing different processing and sintering conditions. Concentrations of nitrogen, oxygen, yttrium and boron were traced from the cen. ter of each cross section to the edges of the cross section. For the $2140{ }^{\circ} \mathrm{C}$ sintering temperature no gradients were observed for nitrogen, yttrium, or boron for sinter times of 1 and $2 \mathrm{hr}$; nor were gradients observed for powder grinding times of 24, 100, or $300 \mathrm{hr}$. However, traces for oxygen did show a decrease from the sample centers to the sample edges. This decrease averaged about 10 percent for 18 measurements but could not be correlated with sinter conditions. A 5 percent decrease in oxygen at the surface of a bar sintered 
at the lower temperature of $2050{ }^{\circ} \mathrm{C}$ was measured. In no case where bar surfaces had been in contact with the $B N$ setter discs was there any indication of boron diffusion into the $\mathrm{Si}_{3} \mathrm{~N}_{4}$ bars.

\section{Flexural Strength}

Table IV lists the flexural strength results for the 21 batches of NASA $6 \mathrm{~S} \mathrm{Si}_{3} \mathrm{~N}_{4}$ evaluated. The number of test bars, average flexural strength and standard deviation for room temperature, 1200 and $1370{ }^{\circ} \mathrm{C}$ tests are compared. The average strengths of Baseline 6Y, originally reported in reference 5 , were 548,393 , and $382 \mathrm{MPa}$ at room temperature, 1200 and $1370^{\circ} \mathrm{C}$ respectively. The most improved NSA $6 Y \mathrm{Si}_{3} \mathrm{~N}_{4}$, batch 31 , had average strengths of 857,544 , and $462 \mathrm{MPa}$ at room temperature, 1200 and $1370^{\circ} \mathrm{C}$, respectively.

Effects of powder grinding time, sintering time, and sintering temperature on flexural strength of NASA $6 \mathrm{~S} \mathrm{Si}_{3} \mathrm{~N}_{4}$ are shown by bar charts in figures 13 to 15 , respectively. Density values are included in the figures. The effect of increasing grinding time on flexural strength (fig. 13) was inconsistent in that only at $1370{ }^{\circ} \mathrm{C}$ was there a progressive strength improvement from 24 to 100 to $300 \mathrm{hr}$ of grinding. However for $6 \mathrm{Y}$ batch 25 , ground $300 \mathrm{hr}$, strength improvements over batches 15 and 16 ground $24 \mathrm{hr}$ were also measured at room temperature and $1200{ }^{\circ} \mathrm{C}$. At 1200 and $1370{ }^{\circ} \mathrm{C}$, t-tests indicated that batch 25 was stronger than the baseline batch at the 95 percent significance level. The higher strengths of batch $25,715,540$, and $467 \mathrm{MPa}$ at room temperature, 1200 and $1370{ }^{\circ} \mathrm{C}$, respectively, correlated with the higher density of $3.28 \mathrm{~g} / \mathrm{cm}^{3}$ compared to $3.22 \mathrm{~g} / \mathrm{cm}^{3}$ for batches 15 and 16 . Figure 14 11lustrates that increased sinter time was also beneficial in improving flexural strength at room temperature. Batches 17 and 20 , sintered for $2 \mathrm{hr}$ (density $3.22 \mathrm{~g} / \mathrm{cm}^{3}$ ) had a flexural strength of $648 \mathrm{MPa}$ compared to $503 \mathrm{MPa}$ for batch $26 \mathrm{~B}$ sintered for $1 \mathrm{hr}$ (density $3.18 \mathrm{~g} / \mathrm{cm}^{3}$ ). A t-test substantiated this difference at the 95 percent significance level. At intermediate sinter times, strengths were inconsistent in that batch 23 , sintered for $1.25 \mathrm{hr}$ was stronger than batches 18 and 19 sintered for $1.5 \mathrm{hr}$. As shown in figure 15 , it was found that a sinter temperature of $2050{ }^{\circ} \mathrm{C}$, compared to the standard $2140{ }^{\circ} \mathrm{C}$ sinter temperature, resulted in the lesser strengths of 531 and $354 \mathrm{MPa}$ at room temperature and $1370{ }^{\circ} \mathrm{C}$ respectively for batch 21 in comparison to strengths of 648 and $441 \mathrm{MPa}$ at room temperature and $1370{ }^{\circ} \mathrm{C}$, respectively, for batches 17 and 20. These strength differences were substantiated in $t$-tests at the 95 percent significance level. The lower strengths for batch 21 sintered at $2050{ }^{\circ} \mathrm{C}$ correlated with a density of only $3.05 \mathrm{~g} / \mathrm{cm}^{3}$ in comparison to a den. sity of $3.22 \mathrm{~g} / \mathrm{cm}^{3}$ for the stronger batches 17 and 20 .

Reducing $B N$ setter contact was found to be very beneficial in improving the room temperature strength of 100 and $300 \mathrm{hr}$ ground $6 \mathrm{Y} \mathrm{Si}_{3} \mathrm{~N}_{4}$ as shown in figure 16. However, this benefit was absent at $1370{ }^{\circ} \mathrm{C}$ where strengths were all about $415 \mathrm{MPa}$. Batches 11 and 12 , ground for 100 and $300 \mathrm{hr}$, respectively, and sintered with maximum $B N$ contact, had room temperature strengths of 487 and $589 \mathrm{MPa}$, respectively. In comparison, batches 13 and 14 ground for 100 and $300 \mathrm{hr}$, respectively and sintered with minimum BN contact had room temperature strengths of 684 and 746 , respectively. These room temperature strength differences were also supported by $t$-tests at the 95 percent significance level. Differences in $B N$ setter contact were not reflected in density differences. 
The combined effect of adjusting sinter height for better top to bottom bar uniformity, plus 20 and $10 \mu \mathrm{m}$ wet sieveing of as received and ground powders respectively, which were performed with $6 Y$ batch 31 , is shown in figure 17. In the figure, batch 31 is compared with batch 25 , with densities and standard deviations included. At room temperature, batch 31 exhibited a strength of $857 \mathrm{MPa}$ in comparison to a strength of $715 \mathrm{MPa}$ for batch 25 . The room temperature standard deviation for batch 31 was reduced to only $36 \mathrm{MPa}$ from $96 \mathrm{MPa}$ for batch 25 . The room temperature strength difference was supported by $t$-test at the 95 percent significance level. Although the 1200 and $1370{ }^{\circ} \mathrm{C}$ strengths for batches 25 and 31 were the same, batch 31 also had lower standard deviations than batch 25 at 1200 and $1370{ }^{\circ} \mathrm{C}$. The improved room temperature strength and lower standard deviations at room temperature, 1200 and $1370{ }^{\circ} \mathrm{C}$ for $6 \mathrm{Y}$ batch 31 attest to the benefits of sinter height adjustment and wet sieveing.

Weibull moduli have not been reported to this point since an insufficient number of samples were tested for the computation of reliable values. For a sample size of 10 , at the 90 percent confidence level the Weibull slope error is approximately +36 to -46 percent of the expected value (ref. 11). With this qualification, the Weibull moduli were calculated for 6Y batch 31. At room temperature, 1200 and $1370^{\circ} \mathrm{C}$ the Weibull moduli were $24.6,17.7$, and 8.4 . These values compare very favorably with the corresponding Weibull moduli 5.5, 8.9, and 11 for $6 \mathrm{Y}$ Baseline $\mathrm{Si}_{3} \mathrm{~N}_{4}$.

Figure 18 presents an abbreviated stepwise summary of strength improvements for NASA $6 Y \mathrm{Si}_{3} \mathrm{~N}_{4}$. Included in the bar chart are $6 Y$ batch densities and standard deviations, plus the parameter levels of powder processing and sintering. The cumulative positive effects of increasing powder grinding time from 24 to $300 \mathrm{hr}$, increasing sinter time from 1 to $2 \mathrm{hr}$, minimizing BN setter contact, adjusting sinter height, and utilizing powder wet sieving procedures are illustrated. In progressing from batch to batch (baseline to 28 to 29 to $31)$, room temperature strength continually increased, with an overall improvement of 56 percent and an over three-fold reduction in standard deviation.

Percentage strength improvements were less spectacular at 38 and 21 percent for 1200 and $1370{ }^{\circ} \mathrm{C}$, respectively. It should be noted that densities improved from $3.12 \mathrm{~g} / \mathrm{cm}^{3}$ for baseline batch to $3.24 \mathrm{~g} / \mathrm{cm}^{3}$ for batch 31 .

\section{Fractography}

Assessments of fracture origins are presented in detail in tables $V$ to $V 1 l$ for flexural tests at room temperature, 1200 and $1370{ }^{\circ} \mathrm{C}$, respectively. This information was assembled by SEM examination of the fracture surfaces of 608 test bars and includes the instances where neither the critical flaw responsible for fallure nor the locale of the flaw could be identified. At room temperature and $1200{ }^{\circ} \mathrm{C}$ about two-thirds of the critical flaws could be iden-. tified, while at $1370^{\circ} \mathrm{C}$, about three-fourths of the critical flaws were identified. Critical flaws were categorized into 10 types.

Overall, the combination of surface and subsurface pores was dominant as the prime critical flaw at all test temperatures. Examples of these pores are given in SEM fractographs figures $19(a)$ and (b) along with the measured fracture stresses. As was observed in previous work at Lewis in establishing the baseline properties of NASA $6 \mathrm{Y} \mathrm{Si}_{3} \mathrm{~N}_{4}$ (ref. 5), no correlation between strength and flaw size was found. Examples of a seam (narrow subsurface void), critical 
flaw, and a subsurface agglomerate critical flaw are given in figures $20(a)$ and (b) along with the measured fracture stresses.

For $6 \mathrm{Y}$ batch 31 , the most improved batch, the critical flaw causing fracture was a large grain in all 10 tests at both room temperature and $1370{ }^{\circ} \mathrm{C}$, and in 6 of 10 tests at $1200{ }^{\circ} \mathrm{C}$. These columnar grains were 40 to $80 \mu \mathrm{m}$ long and 10 to $30 \mu \mathrm{m}$ wide. A typical columnar grain aspect ratio was about $5: 1$. Examples of these columnar grain critical flaws are presented in the low and high magnification SEM fractographs in figures 21 through 25 . Figure 21 shows a columnar grain in the fracture surface at the tensile edge of a test bar which failed at $905 \mathrm{MPa}$ at room temperature. The shallow impressions in the columnar grain were frequently observed on the columnar grains causing failure. Figure 22 shows a columnar grain of hexagonal cross section protruding from the fracture surface of a bar which failed at $535 \mathrm{MPa}$ at $1200{ }^{\circ} \mathrm{C}$. In figure 23 a group of several columnar grains was the fracture origin for $1370{ }^{\circ} \mathrm{C}$ fallure at $534 \mathrm{MPa}$. And in another $1370^{\circ} \mathrm{C}$ fracture (fig. 24), the columnar grain causing fallure at $419 \mathrm{MPa}$ appeared to contain a great deal of fine porosity in addition to the shallow impressions previousiy mentioned. Lastly, in fig. ure 2.5 the planar imprint of the large columnar grain responsible for $1370^{\circ} \mathrm{C}$ failure at $430 \mathrm{MPa}$ is shown.

Examination of the columnar grains in the SEM using energy dispersive $x$-ray analysis showed that only silicon was present. And the electron probe microanalyzer indicated that only silicon and nitrogen were present and in quantities corresponding to $\mathrm{Si}_{3} \mathrm{~N}_{4}$.

It is suggested that these large columnar grains are $\mathrm{B} . \mathrm{Si}_{3} \mathrm{~N}_{4}$ that nucleated and grew early in the liquid phase sintering process and were subsequently encroached upon by smaller columnar grains resulting in the shallow impressions seen on the large columnar grain surfaces. Many times, planar imprints in fracture surfaces were noted indicating where a large columnar grain had been pulled away ( $f$ ig. 25). In the planar imprint can be seen an outline of the matrix microstructure consisting of much smaller grains and an occasional pore. In some instances these small grains are framed with what is likely oxynitride glass phase.

Although the presence of the large columnar grains as critical flaws was most dominant for $6 Y$ batch 31 , these grains acting as critical flaws, were also present for batches 14 and 25, both ground $300 \mathrm{hr}$; for batches 13, 17, and 29, ground $100 \mathrm{hr}$; and for batch 15, ground $24 \mathrm{hr}$. The frequency of appearance of the columnar grain critical flaws varied with the powder grinding time and thus the fineness of the powder. This powder fineness may promote rapid $\mathrm{Si}_{3} \mathrm{~N}_{4}$ solu. tioning and $\mathrm{B}-\mathrm{Si}_{3} \mathrm{~N}_{4}$ grain precipitation and growth at certain sites during sin. tering of the $\mathrm{Si}_{3} \mathrm{~N}_{4}$ test bars. Further, it was observed that the incidence of failures due to the columnar grains was greatest for $1370{ }^{\circ} \mathrm{C}$ tests. Although no slow crack growth was noted during fractographic examinations, nor was there any incidence of nonlinear load deflection behavior in $1370^{\circ} \mathrm{C}$ flexure tests, it may be that softening of the oxynitride glass phase at the surface of the large columnar grains resulted in movement at these interfaces triggering fracture.

The absence in batch 31 of the previously dominant pore critical flaw in NASA $6 Y$ is reasoned to result from reduction of agglomerates by the longer grinding time of $300 \mathrm{hr}$, and by agglomerate elimination due to the powder wet sieveing procedures. Also, use of the powder wet sieveing procedures reduces 
the size of certain impurity particles in green-pressed bars which vaporize during sintering leaving voids in the sintered bars.

The occurrence of large, high aspect ratio grains like those observed in this study has been reported by Mangels (ref. 12), Mangels and Tennenhouse (ref. 13), and most recently, Govila et al. (ref. 14), all for $\mathrm{Y}_{2} \mathrm{O}_{3}$-doped sintered reaction bonded $\mathrm{Si}_{3} \mathrm{~N}_{4}$. These grains were reported to become more prevalent and larger as sintering temperatures were increased above $1800{ }^{\circ} \mathrm{C}$. In reference 13 it was reasoned that the large needle-shaped grains, growing from a liquid phase, were $\mathrm{B}-\mathrm{Si}_{3} \mathrm{~N}_{4}$ since only silicon was found by nondispersive $x$-ray analysis of the grains. And in reference 14 it was reported that for an 8 percent $\mathrm{Y}_{2} \mathrm{O}_{3}$-doped siip cast sintered reaction bonded $\mathrm{Si}_{3} \mathrm{~N}_{4}, \mathrm{~B}_{-} \mathrm{Si}_{3} \mathrm{~N}_{4}$ needles were dominant fracture origins in flexural tests at 7 temperatures from room temperature to $1400^{\circ} \mathrm{C}$. Needles at fallure sites were reported to be 10 to $30 \mu \mathrm{m}$ wide and 100 to $150 \mu \mathrm{m}$ long, often acting as cracks by cleaving in two or pulling out of the matrix. Again, it was suggested that these grains grew during liquid phase sintering. It was suggested in reference 14 that iron impurity may promote needle-growth. Iron content of the sintered reaction bonded $\mathrm{Si}_{3} \mathrm{~N}_{4}$ of reference 14 was reported to be $3100 \mathrm{ppm}$. NASA $6 \mathrm{Y}$ sintered $\mathrm{Si}_{3} \mathrm{~N}_{4}$ contained about $1400 \mathrm{ppm}$ iron. Average strength and standard deviation for 15 bars tested in four-point flexure at room temperature for the $\mathrm{Si}_{3} \mathrm{~N}_{4}$ discussed in reference 12 were 696 and $83 \mathrm{MPa}$, respectively.

\section{CONCLUSIONS}

1. The sensitivity of conventional $x$-radiography to slight density variations (case/core) and to within bar porosity segregation and distribution was demonstrated for sintered $\mathrm{Si}_{3} \mathrm{~N}_{4}$.

2. Conventional $x$-radiography was found to be very beneficial in guiding powder processing and sintering parameter changes to improve the absolute den. sity and density uniformity of sintered $\mathrm{Si}_{3} \mathrm{~N}_{4}$.

3. Improvements in structure by increasing powder grinding time, sinter time, minimizing BN setter contact, adjusting sinter height for improved temperature uniformity, and incorporating powder wet sieving, guided by $x$-radiographic characterization, correlated with successive improvements in the mechanical properties of sintered $\mathrm{Si}_{3} \mathrm{~N}_{4}$.

4. The final result of $\mathrm{Si}_{3} \mathrm{~N}_{4}$ powder processing and sintering parameter adjustments over baseline conditions was an increase in density from 3.12 to $3.24 \mathrm{~g} / \mathrm{cm}^{3}$, with room temperature, 1200 and $1370{ }^{\circ} \mathrm{C}$, four point flexural strength increases from 548 to 857,393 to 544 , and 382 to $462 \mathrm{MPa}$, respectively.

5. The previously dominant critical flaw type, a pore, was changed by powder processing and sintering procedure adjustments to a large columnar grain which was less detrimental to strength properties.

6. Nitrogen and yttrium levels are maintained throughout sintered $\mathrm{Si}_{3} \mathrm{~N}_{4}$ bars while oxygen decreases approximately 10 percent as determined by electron probe microanalyzer. No diffusion of boron into silicon nitride occurs from contact with the $B N$ setters. 


\section{REFERENCES}

1. A.G. Evans, "Structural Reliability: A Processing-Dependent Phenomenon," J. Am. Ceram. Soc., 65 (3) 127-37 (1982).

2. A.G. Evans, "Considerations of Inhomogeneity Effects in Sintering," $\underline{\mathrm{J}}$. Am. Ceram. Soc., 65 (10) 497-501 (1982).

3. H.K. Bowen, "Basic Research Needs on High Temperature Ceramics for Energy Applications." Mater. Sci. Eng., 44 1-56 (1980).

4. S.J. Klima, "NDE for Heat Engine Ceramics," NASA 1M-86949, 1984.

5. D.M. Mieskowski, W.A. Sanders, and L.A. Pierce, "Reliability of Two Sintered Silicon Nitride Materials," NASA TM-87092, 1985.

6. R. Halmshaw, Industrial Radiology, Theory and Practice, Applied Science, London, 1982.

7. R. McMaster, Nondestructive Testing Handbook, Vol. I, 13-27, Ronald Press, New York, 1959.

8. S.J. Klima and G.Y. Baaklini, "Ultrasonic Characterization of Structural Ceramics," NASA CP-2383, 1984.

9. G.Y. Baaklini, J.D. Kiser, and D.J. Roth, "Radiographic Detectability Limits for Seeded Voids in sintered Silicon Carbide and Stlicon Nitride," NASA TM-86945, 1984.

10. G.Y. Baaklini and D.J. Roth, "Probability of Detection of Internal Voids in Structural Ceramics Using Microfocus Radiography." NASA TM-87164, 1985.

11. R.A. Jeryan, "Use of Statistics in Ceramic Design and Evaluation," pp. 35-51 in Ceramics for High Performance Applications - II, Brook Hill Publishing Company, Chestnut Hill, MA, 1978.

12. J.A. Mangels, "Sintered Reaction-bonded Silicon Nitride," Ceram. Eng. Sci. Proc., 2 [7-8] 589-603 (1981).

13. J.A. Mangels and G.J. Tennenhouse, "Sintering Behavior and Microstructural Development of Yttrium-Doped Reaction-Bonded Silicon Nitride," Am. Ceram. Soc. Bull., 60 [12] 1306-10 (1981).

14. R.K. Govila, J.A. Mangels, and J.R. Baer, "Fracture of Yttria-Doped, Sintered Reaction-Bonded Silicon Nitride," J. Am. Ceram. Soc.. 68 [7]. 413-418 (1985). 
TABLE I. - CHARACTERIZATION OF SILICON NITRIOE, OXIDE POWDERS, AND $\mathrm{Si}_{3} \mathrm{~N}_{4}-\mathrm{SiO}_{2}-\mathrm{Y}_{2} \mathrm{O}_{3}$ COMPOSITION NASA GY AFTER MILLING

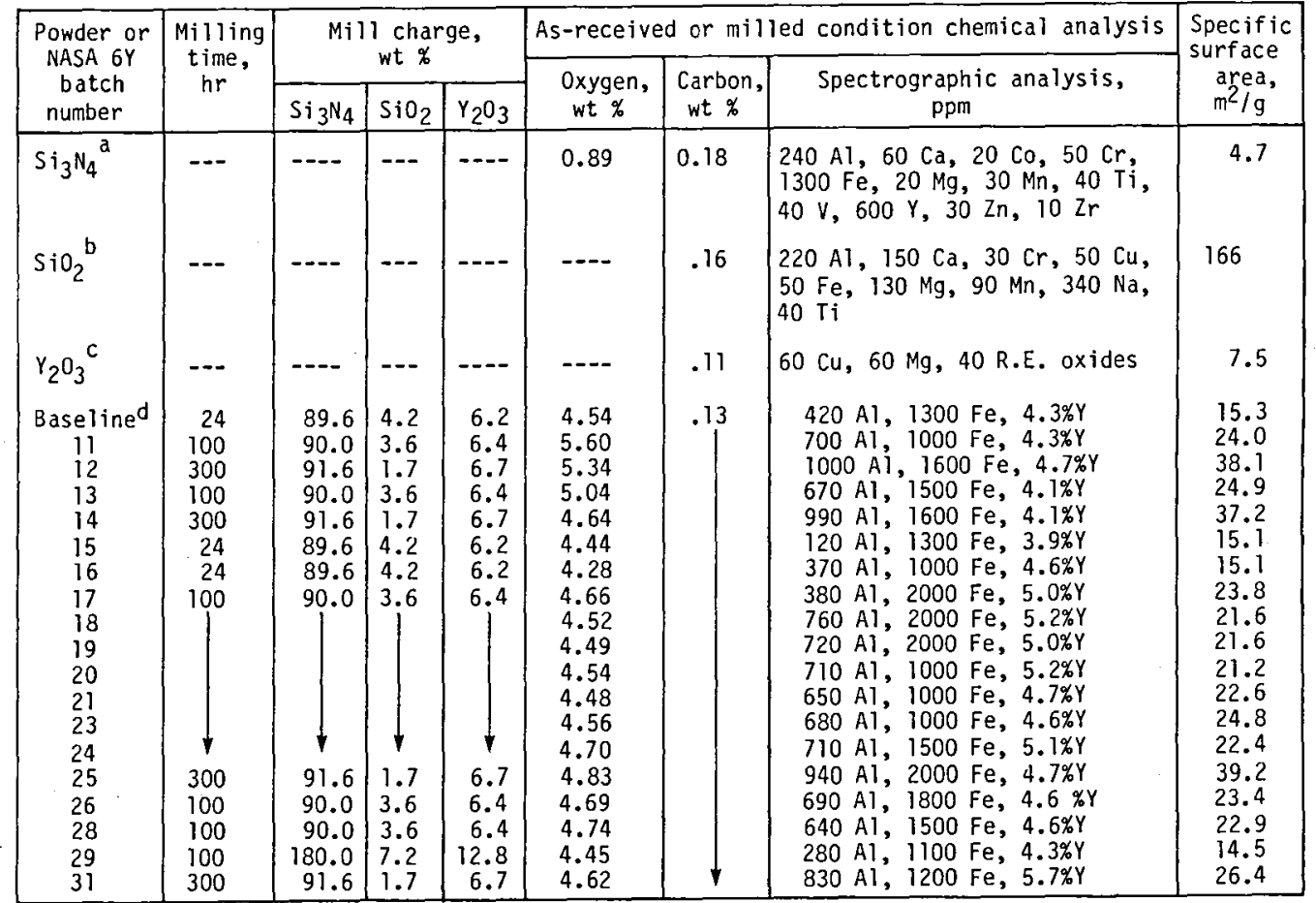

AKBI-AME, High purity, 99.5 percent, 83.7 percent $\alpha, 15.7$ percent $B, 0.6$ percent Free $S i$. b Apache Chemicals Inc., Code $6846,99.99$ percent CMolycorp, $5600,99.9$ percent.

Made up of five separate batches. 
TABLE II. - SINTERING CONDITIONS AND RESULTS FOR $\mathrm{Si}_{3} \mathrm{~N}_{4}-\mathrm{SiO}_{2}$ COMPOSITION NASA 6Y

\begin{tabular}{|c|c|c|c|c|c|c|c|c|}
\hline \multirow{2}{*}{$\begin{array}{c}\text { NASA } 6 Y \\
\text { batch } \\
\text { number }\end{array}$} & \multirow{2}{*}{$\begin{array}{l}\text { Milling } \\
\text { time, } \\
\text { hr }\end{array}$} & \multicolumn{4}{|c|}{ Sintering conditions } & \multicolumn{3}{|c|}{ Sintering results } \\
\hline & & Temp., & $\begin{array}{c}\text { Time, } \\
\text { hr }\end{array}$ & $\begin{array}{c}\text { Nitrogen } \\
\text { pressure, } \\
\text { MPa }\end{array}$ & $\begin{array}{l}\text { Extent } \\
\text { of } B N \\
\text { setter } \\
\text { contact }^{b}\end{array}$ & $\begin{array}{l}\text { Average } \\
\text { weight } \\
\text { loss, } \\
\text { percent }\end{array}$ & $\begin{array}{c}\text { Average } \\
\text { width } \\
\text { shrinkage, } \\
\text { percent }\end{array}$ & $\begin{array}{l}\text { Average } \\
\text { machined } \\
\text { density, } \\
\text { g/cm }\end{array}$ \\
\hline $\begin{array}{c}\text { Baseline } \\
11 \\
12 \\
13 \\
14 \\
15 \\
16 \\
17 \\
18 \\
19 \\
20 \\
21 \\
23 \\
24 A \\
24 B \\
25 \\
26 \mathrm{~A} \\
26 \mathrm{~B} \\
28^{\mathrm{C}} \\
29^{\mathrm{C}}, \mathrm{d} \\
31^{\mathrm{C}}, \mathrm{d}\end{array}$ & $\begin{array}{r}24 \\
100 \\
300 \\
100 \\
300 \\
24 \\
24 \\
100 \\
1\end{array}$ & $\begin{array}{c}\downarrow \\
2050 \\
2140 \\
\downarrow\end{array}$ & $\begin{array}{l}1 \\
1 \\
2 \\
2 \\
2 \\
1.5 \\
1.5 \\
2 \\
2 \\
1.25 \\
1.25 \\
2 \\
2 \\
1 \\
1 \\
2 \\
2 \\
2\end{array}$ & \begin{tabular}{|}
$\left.\right|_{5.0} ^{2.5}$ \\
1 \\
3.5 \\
3.5 \\
5.0 \\
3.5 \\
5.0 \\
1 \\
1
\end{tabular} & $\begin{array}{c}\text { Max. } \\
\text { Max. } \\
\text { Max. } \\
\text { Min. } \\
\mid\end{array}$ & $\begin{array}{l}3.85 \\
5.14 \\
5.74 \\
4.93 \\
5.42 \\
5.10 \\
4.44 \\
4.39 \\
3.25 \\
2.96 \\
2.81 \\
1.65 \\
4.77 \\
4.15 \\
4.67 \\
4.88 \\
3.50 \\
3.14 \\
3.77 \\
3.06 \\
3.71\end{array}$ & $\begin{array}{l}15.6 \\
17.6 \\
18.0 \\
17.6 \\
17.5 \\
17.2 \\
16.8 \\
17.3 \\
16.8 \\
16.9 \\
17.2 \\
14.9 \\
17.6 \\
17.2 \\
17.5 \\
17.8 \\
17.5 \\
17.4 \\
17.3 \\
16.1 \\
17.3\end{array}$ & $\begin{array}{l}3.12 \\
3.23 \\
3.25 \\
3.24 \\
3.24 \\
3.22 \\
3.23 \\
3.23 \\
3.21 \\
3.22 \\
3.22 \\
3.05 \\
3.24 \\
3.26 \\
3.26 \\
3.28 \\
3.20 \\
3.18 \\
3.21 \\
3.23 \\
3.24\end{array}$ \\
\hline
\end{tabular}

$\mathrm{a}_{\mathrm{E}}$ ach composition number represents 30 bars except for baseline which represents 150 bars ( 5 batches) and for composition 23, 24A, 24B, 26A, 26B, and 28 which represent 15 bars each.

Max. refers to full contact of narrow sinter bar faces with BN setter discs.

Min. refers to end only contact of narrow sinter bar faces with BN setter discs.

CSinter cup raised $3.8 \mathrm{~cm}$.

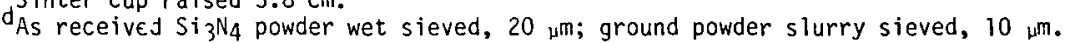


TABLE III. - GRAIN SIZE AND MORPHOLOGY OF $\mathrm{Si}_{3} \mathrm{~N}_{4}-\mathrm{SiO}_{2}-\mathrm{Y}_{2} \mathrm{O}_{3}$ COMPOSITION NASA $6 Y$ SINTERED AT $2140^{\circ} \mathrm{C}$

\begin{tabular}{|c|c|c|c|c|c|c|c|c|}
\hline \multirow{2}{*}{$\begin{array}{c}\text { NASA } 6 Y \\
\text { batch } \\
\text { number }\end{array}$} & \multirow{2}{*}{$\begin{array}{l}\text { Powder } \\
\text { milling } \\
\text { time, } \\
\text { hr }\end{array}$} & \multirow{2}{*}{$\begin{array}{l}\text { Sinter } \\
\text { time, } \\
\text { hr }\end{array}$} & \multirow{2}{*}{\multicolumn{2}{|c|}{$\begin{array}{c}\text { Equiaxgrain } \\
\text { size range, } \\
\mu \mathrm{m}\end{array}$}} & \multicolumn{4}{|c|}{ Columnar grains } \\
\hline & & & & & Width & $\begin{array}{l}\text { h range, } \\
\text { um }\end{array}$ & $\begin{array}{c}\text { Aspect ratio } \\
\text { range, } \\
\mu^{m}\end{array}$ & $\begin{array}{c}\text { Estimated, } \\
\text { vol } \%\end{array}$ \\
\hline $\begin{array}{c}\text { Baseline-case } \\
\text { Baseline-core } \\
13 \\
14 \\
16 \\
20 \\
21^{\mathrm{a}} \\
23 \text {-Case } \\
23 \text {-Core } \\
26 \mathrm{~A} \\
26 \mathrm{~B} \\
28^{\mathrm{b}}\end{array}$ & $\begin{array}{r}24 \\
24 \\
100 \\
300 \\
24 \\
100 \\
1\end{array}$ & $\begin{array}{l}1 \\
1 \\
2 \\
2 \\
2 \\
1.25 \\
1.25 \\
1 \\
1 \\
2\end{array}$ & $\begin{array}{l}0.3 \\
.3 \\
.2 \\
.2 \\
.5 \\
.25 \\
.2 \\
.2 \\
.2 \\
.2 \\
.25 \\
.2\end{array}$ & $\begin{array}{l}\text { to } 2.5 \\
\text { to } 4.0 \\
\text { to } 3.5 \\
\text { to } 3.0 \\
\text { to } 5.5 \\
\text { to } 3.5 \\
\text { to } 2.0 \\
\text { to } 3.0 \\
\text { to } 5.0 \\
\text { to } 3.0 \\
\text { to } 3.0 \\
\text { to } 3.5\end{array}$ & $\begin{array}{l}0.25 \\
.35 \\
.4 \\
.25 \\
.3 \\
.2 \\
.2 \\
.2 \\
.2 \\
.2 \\
.15 \\
.2\end{array}$ & $\begin{array}{l}\text { to } 3.0 \\
\text { to } 3.5 \\
\text { to } 2.0 \\
\text { to } 2.0 \\
\text { to } 4.0 \\
\text { to } 3.0 \\
\text { to } 2.0 \\
\text { to } 3.0 \\
\text { to } 3.0 \\
\text { to } 2.5 \\
\text { to } 2.0 \\
\text { to } 5.0\end{array}$ & $\begin{array}{l}1: 2 \text { to } 1: 7 \\
1: 2 \text { to } 1: 6 \\
1: 2 \text { to } 1: 14 \\
1: 2 \text { to } 1: 8 \\
1: 2 \text { to } 1: 5 \\
1: 2 \text { to } 1: 8 \\
1: 2 \text { to } 1: 9 \\
1: 2 \text { to } 1: 8 \\
1: 2 \text { to } 1: 9 \\
1: 2 \text { to } 1: 8 \\
1: 3 \text { to } 1: 8 \\
1: 2 \text { to } 1: 7\end{array}$ & $\begin{array}{l}50 \\
70 \\
40 \\
20 \\
60 \\
50 \\
30 \\
50 \\
20 \\
40 \\
40 \\
50\end{array}$ \\
\hline
\end{tabular}

asintered at $2050^{\circ} \mathrm{C}$.

binter cup raised $3.8 \mathrm{~cm}$.

TABLE IV. - FLEXURAL STRENGTH RESULTS FOR $\mathrm{Si}_{3} \mathrm{~N}_{4}-\mathrm{SiO}_{2}-\mathrm{Y}_{2} \mathrm{O}_{3}$ COMPOSITION NASA $6 Y$ TESTED IN AIR

\begin{tabular}{|c|c|c|c|c|c|c|c|c|c|}
\hline \multirow{3}{*}{$\begin{array}{c}\text { NASA } 6 Y \\
\text { batch } \\
\text { number }\end{array}$} & \multicolumn{9}{|c|}{ Strength results } \\
\hline & \multicolumn{3}{|c|}{ Room temperature } & \multicolumn{3}{|c|}{$1200^{\circ} \mathrm{C}$} & \multicolumn{3}{|c|}{$1370^{\circ} \mathrm{C}$} \\
\hline & $\begin{array}{c}\text { Number } \\
\text { of test } \\
\text { bars, } \\
n\end{array}$ & $\begin{array}{c}\text { Average } \\
\text { flexural } \\
\text { strength, } \\
\text { MPa, } \\
0\end{array}$ & $\begin{array}{l}\text { Standard } \\
\text { deviation, } \\
\text { Mpa, } \\
\text { S }\end{array}$ & $\begin{array}{c}\text { Number } \\
\text { of test } \\
\text { bars, } \\
n\end{array}$ & $\begin{array}{c}\text { Average } \\
\text { flexural } \\
\text { strength, } \\
\text { MPa, } \\
\sigma\end{array}$ & $\begin{array}{l}\text { Standard } \\
\text { deviation, } \\
\mathrm{MPa}, \\
5\end{array}$ & $\begin{array}{c}\text { Number } \\
\text { of test } \\
\text { bars, } \\
n\end{array}$ & $\begin{array}{c}\text { Average } \\
\text { f lexural } \\
\text { strength, } \\
\text { MPa, } \\
\sigma\end{array}$ & $\begin{array}{c}\text { Standard } \\
\text { deviation, } \\
\text { MPa, } \\
\text { s }\end{array}$ \\
\hline $\begin{array}{c}\text { Base 1ine } \\
11 \\
12 \\
13 \\
14 \\
15 \\
16 \\
17 \\
18 \\
19 \\
20 \\
21 \\
23 \\
24 \mathrm{~A} \\
24 \mathrm{~B} \\
25 \\
26 \mathrm{~A} \\
26 \mathrm{~B} \\
28 \\
29 \\
31\end{array}$ & $\begin{array}{l}60 \\
15 \\
15 \\
15 \\
14 \\
10 \\
9 \\
10 \\
1 \\
1 \\
15 \\
15 \\
15 \\
10 \\
15 \\
15 \\
10 \\
10 \\
10\end{array}$ & $\begin{array}{l}548 \\
487 \\
589 \\
684 \\
746 \\
714 \\
608 \\
647 \\
608 \\
571 \\
650 \\
531 \\
632 \\
587 \\
619 \\
715 \\
479 \\
503 \\
672 \\
732 \\
857\end{array}$ & $\begin{array}{r}117 \\
78 \\
141 \\
100 \\
122 \\
43 \\
88 \\
98 \\
133 \\
101 \\
92 \\
85 \\
168 \\
132 \\
128 \\
96 \\
111 \\
143 \\
74 \\
108 \\
36\end{array}$ & $\begin{array}{c}58 \\
-- \\
-- \\
-- \\
-- \\
10 \\
1 \\
-- \\
-- \\
10 \\
-- \\
-- \\
-- \\
10 \\
-- \\
-- \\
-- \\
9 \\
10\end{array}$ & $\begin{array}{l}393 \\
--- \\
--- \\
--- \\
--- \\
479 \\
458 \\
425 \\
484 \\
--- \\
--- \\
433 \\
--- \\
--- \\
--- \\
540 \\
--- \\
--- \\
--- \\
522 \\
544\end{array}$ & $\begin{array}{l}53 \\
-- \\
-- \\
-- \\
-- \\
75 \\
45 \\
39 \\
52 \\
-- \\
-- \\
83 \\
-- \\
-- \\
-- \\
80 \\
-- \\
-- \\
-- \\
55 \\
33\end{array}$ & $\begin{array}{l}29 \\
13 \\
14 \\
15 \\
14 \\
10 \\
1 \\
-- \\
-- \\
10 \\
-- \\
-- \\
10 \\
-- \\
-- \\
-- \\
10 \\
10\end{array}$ & $\begin{array}{l}382 \\
417 \\
418 \\
405 \\
425 \\
420 \\
384 \\
441 \\
460 \\
--- \\
--- \\
354 \\
--- \\
--- \\
--- \\
467 \\
--- \\
--- \\
--- \\
423 \\
462\end{array}$ & $\begin{array}{l}39 \\
45 \\
60 \\
35 \\
45 \\
53 \\
51 \\
25 \\
50 \\
-- \\
-- \\
63 \\
-- \\
-- \\
-- \\
75 \\
-- \\
-- \\
-- \\
43 \\
59\end{array}$ \\
\hline
\end{tabular}


TABLE V. - ROOM TEMPERATURE FLEXURE TEST FRACTOGRAPHY RESULTS FOR $\mathrm{Si}_{3} \mathrm{~N}_{4}-\mathrm{Si}_{2}-\mathrm{Y}_{2} \mathrm{O}_{3}$ COMPOSITION NASA $6 Y$

\begin{tabular}{|c|c|c|c|c|c|c|c|c|c|c|c|c|c|}
\hline \multirow{2}{*}{$\begin{array}{l}\text { NASA } 6 Y \\
\text { batch } \\
\text { number }\end{array}$} & \multirow{2}{*}{$\begin{array}{l}\text { Number } \\
\text { of test } \\
\text { bars }\end{array}$} & \multicolumn{12}{|c|}{ Assessment of fracture origins } \\
\hline & & $\begin{array}{l}\text { Undeter- } \\
\text { mined } \\
\text { region }\end{array}$ & $\begin{array}{l}\text { Undeter- } \\
\text { mined } \\
\text { flawb }\end{array}$ & $\begin{array}{l}\text { Sub- } \\
\text { surface } \\
\text { pore }\end{array}$ & $\begin{array}{c}\text { Surface } \\
\text { pore }\end{array}$ & Seamc & $\begin{array}{l}\text { Sub- } \\
\text { surface } \\
\text { agglom. }\end{array}$ & $\begin{array}{l}\text { Surface } \\
\text { agglom. }\end{array}$ & $\begin{array}{l}\text { Large } \\
\text { grain }\end{array}$ & $\begin{array}{l}\text { Surface } \\
\text { defect }\end{array}$ & $\begin{array}{l}\text { Machining } \\
\text { defect }\end{array}$ & $\begin{array}{c}\text { Metallic } \\
\text { inclu- } \\
\text { sion }\end{array}$ & $\begin{array}{l}\text { Conc. of } \\
\text { columnar } \\
\text { grains }\end{array}$ \\
\hline $\begin{array}{c}\text { Baseline } \\
11 \\
12 \\
13 \\
14 \\
15 \\
16 \\
17 \\
18 \\
19 \\
20 \\
21 \\
23 \\
24 A \\
24 B \\
25 \\
26 \mathrm{~A} \\
26 \mathrm{~B} \\
28 \\
29 \\
31\end{array}$ & $\begin{array}{l}\downarrow \\
15 \\
15 \\
15 \\
10 \\
15 \\
15 \\
10 \\
10 \\
10\end{array}$ & $\begin{array}{l}- \\
4 \\
3 \\
7 \\
2 \\
3 \\
2 \\
2 \\
4 \\
2 \\
1 \\
2 \\
5 \\
5 \\
2 \\
1 \\
4 \\
2 \\
- \\
- \\
-\end{array}$ & $\begin{array}{r}25 \\
2 \\
2 \\
2 \\
-- \\
5 \\
2 \\
-- \\
2 \\
1 \\
1 \\
2 \\
4 \\
2 \\
2 \\
1 \\
2 \\
2 \\
2 \\
1 \\
--\end{array}$ & $\begin{array}{r}11 \\
-- \\
6 \\
1 \\
3 \\
-- \\
2 \\
2 \\
1 \\
5 \\
2 \\
1 \\
2 \\
3 \\
4 \\
2 \\
4 \\
2 \\
2 \\
3 \\
--\end{array}$ & $\begin{array}{r}16 \\
1 \\
-- \\
2 \\
2 \\
1 \\
2 \\
-- \\
1 \\
1 \\
1 \\
2 \\
-- \\
3 \\
1 \\
4 \\
1 \\
2 \\
2 \\
2 \\
--\end{array}$ & $\begin{array}{l}- \\
2 \\
1 \\
1 \\
- \\
- \\
1 \\
2 \\
3 \\
1 \\
2 \\
3 \\
1 \\
2 \\
-\end{array}$ & $\begin{array}{l}- \\
2 \\
2 \\
1 \\
2 \\
- \\
1 \\
- \\
- \\
- \\
3 \\
2 \\
- \\
- \\
2 \\
5 \\
1 \\
1 \\
2 \\
- \\
-\end{array}$ & $\begin{array}{l}- \\
1 \\
- \\
- \\
- \\
1 \\
- \\
- \\
- \\
1 \\
- \\
- \\
- \\
1 \\
- \\
- \\
-\end{array}$ & $\begin{array}{c}-- \\
-- \\
-1 \\
4 \\
-- \\
-- \\
-- \\
-- \\
-- \\
-- \\
-- \\
-- \\
1 \\
-- \\
-- \\
-1 \\
10\end{array}$ & $\begin{array}{l}5 \\
- \\
- \\
- \\
- \\
5 \\
1 \\
- \\
1 \\
1 \\
5 \\
- \\
5 \\
2 \\
- \\
-\end{array}$ & $\begin{array}{l}- \\
- \\
- \\
- \\
- \\
- \\
- \\
- \\
- \\
- \\
1 \\
- \\
- \\
- \\
1 \\
- \\
- \\
-\end{array}$ & $\begin{array}{l}8 \\
- \\
- \\
- \\
- \\
- \\
- \\
- \\
- \\
- \\
- \\
- \\
- \\
- \\
- \\
- \\
- \\
- \\
- \\
-\end{array}$ & $\begin{array}{l}- \\
- \\
- \\
5 \\
- \\
- \\
- \\
1 \\
- \\
- \\
- \\
- \\
- \\
- \\
-\end{array}$ \\
\hline Total & 303 & 51 & 60 & 56 & 44 & 28 & 19 & 6 & 17 & 11 & 2 & 8 & 1 \\
\hline \multicolumn{4}{|c|}{ Fracture origins in percent ${ }^{d}$} & 29 & 23 & 14 & 10 & 3 & 9 & 6 & 1 & 4 & 1 \\
\hline
\end{tabular}

a No fracture "burst" pattern.

bF law could not be determined at fracture "burst" origin.

$c_{A}$ narrow subsurface void.

dercentages are based on 193 bars for which fracture origins were identified. 
TABLE VI. - $1200^{\circ} \mathrm{C}$ FLEXURE TEST FRACTOGRAPHY RESULTS FOR $\mathrm{Si}_{3} \mathrm{~N}_{4}-\mathrm{SiO}_{2}-\mathrm{Y}_{2} \mathrm{O}_{3}$ COMPOSITION NASA $6 \mathrm{Y}$

\begin{tabular}{|c|c|c|c|c|c|c|c|c|c|c|c|c|c|}
\hline \multirow{2}{*}{$\begin{array}{c}\text { NASA } 6 Y \\
\text { batch } \\
\text { number }\end{array}$} & \multirow{2}{*}{$\begin{array}{c}\text { Number } \\
\text { of test } \\
\text { bars }\end{array}$} & \multicolumn{12}{|c|}{ Assessment of fracture origins } \\
\hline & & $\begin{array}{l}\text { Undeter- } \\
\text { mined } \\
\text { region }\end{array}$ & $\begin{array}{l}\text { Undeter- } \\
\text { mined } \\
\text { flaw }\end{array}$ & $\begin{array}{l}\text { Sub- } \\
\text { surface } \\
\text { pore }\end{array}$ & $\begin{array}{l}\text { Surface } \\
\text { pore }\end{array}$ & Seamc & $\begin{array}{l}\text { Sub- } \\
\text { surface } \\
\text { agglom. }\end{array}$ & $\begin{array}{l}\text { Surface } \\
\text { agglom. }\end{array}$ & $\begin{array}{l}\text { Large } \\
\text { grain }\end{array}$ & $\begin{array}{l}\text { Surface } \\
\text { defect }\end{array}$ & $\begin{array}{l}\text { Machining } \\
\text { defect }\end{array}$ & $\begin{array}{c}\text { Metallic } \\
\text { inclu- } \\
\text { sion. }\end{array}$ & $\begin{array}{c}\text { Conc. of } \\
\text { columnar } \\
\text { grains. }\end{array}$ \\
\hline $\begin{array}{c}\text { Baseline } \\
15 \\
16 \\
17 \\
18 \\
21 \\
25 \\
29 \\
31\end{array}$ & \begin{tabular}{|}
10 \\
10 \\
9 \\
10
\end{tabular} & $\begin{array}{r}13 \\
1 \\
2 \\
1 \\
3 \\
4 \\
3 \\
1 \\
--\end{array}$ & $\begin{array}{r}12 \\
2 \\
1 \\
2 \\
1 \\
-- \\
-- \\
-- \\
1\end{array}$ & $\begin{array}{l}3 \\
3 \\
2 \\
2 \\
1 \\
5 \\
2 \\
2 \\
3\end{array}$ & $\begin{array}{r}10 \\
1 \\
3 \\
-- \\
2 \\
-- \\
2 \\
1 \\
--\end{array}$ & $\begin{array}{l}1 \\
1 \\
2 \\
5 \\
1 \\
1 \\
1 \\
2 \\
-\end{array}$ & $\begin{array}{l}3 \\
- \\
- \\
- \\
- \\
- \\
- \\
-\end{array}$ & $\begin{array}{l}2 \\
- \\
- \\
- \\
2 \\
- \\
- \\
- \\
-\end{array}$ & $\begin{array}{l}- \\
\overline{1} \\
4 \\
- \\
- \\
- \\
3 \\
6\end{array}$ & $\begin{array}{l}- \\
- \\
- \\
- \\
- \\
- \\
-\end{array}$ & $\begin{array}{l}- \\
- \\
- \\
- \\
- \\
- \\
-\end{array}$ & $\begin{array}{r}14 \\
1 \\
-- \\
1 \\
-- \\
-- \\
2 \\
-- \\
--\end{array}$ & $\begin{array}{l}- \\
- \\
- \\
- \\
- \\
- \\
-\end{array}$ \\
\hline Total & 137 & 28 & 19 & 23 & 19 & 9 & 3 & 4 & 14 & 0 & 0 & 18 & 0 \\
\hline \multicolumn{4}{|c|}{ Fracture origins in percent ${ }^{d}$} & 26 & 21 & 10 & 3 & 4 & 16 & 0 & 0 & 20 & 0 \\
\hline
\end{tabular}

aNo fracture "burst" pattern.

bFlaw could not be determined at fracture "burst" origin.

$C_{A}$ narrow subsurface void.

Percentages are based on 90 bars for which fracture origins were identified.

TABLE VII. - $1370{ }^{\circ} \mathrm{C}$ FLEXURE TEST FRACTOGRAPHY RESULTS FOR Si $\mathrm{N}_{4}-\mathrm{SiO}_{2}-\mathrm{Y}_{2} \mathrm{O}_{3}$ COMPOSITION NASA $6 \mathrm{Y}$

\begin{tabular}{|c|c|c|c|c|c|c|c|c|c|c|c|c|c|}
\hline \multirow{2}{*}{$\begin{array}{c}\text { NASA } 6 Y \\
\text { batch } \\
\text { number }\end{array}$} & \multirow{2}{*}{$\begin{array}{l}\text { Number } \\
\text { of test } \\
\text { bars }\end{array}$} & \multicolumn{12}{|c|}{ Assessment of fracture origins } \\
\hline & & $\begin{array}{l}\text { Undeter- } \\
\text { mineda } \\
\text { region }\end{array}$ & $\begin{array}{l}\text { Undeter- } \\
\text { minedb } \\
\text { flaw }\end{array}$ & $\begin{array}{l}\text { Sub- } \\
\text { surface } \\
\text { pore }\end{array}$ & $\begin{array}{c}\text { Surface } \\
\text { pore }\end{array}$ & Seamc & $\begin{array}{l}\text { Sub- } \\
\text { surface } \\
\text { agglom. }\end{array}$ & $\begin{array}{l}\text { Surface } \\
\text { agglom. }\end{array}$ & $\begin{array}{l}\text { Large } \\
\text { grain }\end{array}$ & $\begin{array}{l}\text { Surface } \\
\text { defect }\end{array}$ & $\begin{array}{l}\text { Machining } \\
\text { defect }\end{array}$ & $\begin{array}{c}\text { Metallic } \\
\text { inclu- } \\
\text { sion }\end{array}$ & $\begin{array}{l}\text { Conc. of } \\
\text { columnar } \\
\text { grains }\end{array}$ \\
\hline $\begin{array}{c}\text { Baseline } \\
11 \\
12 \\
13 \\
14 \\
15 \\
16 \\
17 \\
18 \\
21 \\
25 \\
29 \\
31\end{array}$ & $\begin{array}{c}29 \\
15 \\
15 \\
15 \\
14 \\
10 \\
1\end{array}$ & $\begin{array}{l}- \\
4 \\
3 \\
1 \\
- \\
2 \\
1 \\
1 \\
1 \\
4 \\
- \\
- \\
-\end{array}$ & $\begin{array}{l}5 \\
2 \\
2 \\
4 \\
2 \\
3 \\
2 \\
1 \\
- \\
1 \\
- \\
2 \\
-\end{array}$ & $\begin{array}{l}7 \\
2 \\
4 \\
3 \\
1 \\
1 \\
1 \\
2 \\
2 \\
3 \\
1 \\
3 \\
-\end{array}$ & $\begin{array}{l}5 \\
2 \\
1 \\
1 \\
1 \\
- \\
1 \\
- \\
- \\
2 \\
-\end{array}$ & $\begin{array}{l}5 \\
3 \\
4 \\
1 \\
2 \\
1 \\
4 \\
- \\
2 \\
1 \\
- \\
2 \\
-\end{array}$ & $\begin{array}{l}1 \\
- \\
- \\
- \\
- \\
- \\
- \\
- \\
- \\
- \\
-\end{array}$ & $\begin{array}{l}1 \\
- \\
- \\
- \\
- \\
- \\
- \\
- \\
- \\
-\end{array}$ & $\begin{array}{r}-- \\
-- \\
-- \\
1 \\
7 \\
2 \\
-- \\
5 \\
-- \\
-- \\
6 \\
1 \\
10\end{array}$ & $\begin{array}{l}- \\
- \\
- \\
- \\
- \\
- \\
- \\
- \\
- \\
- \\
-\end{array}$ & $\begin{array}{l}- \\
- \\
- \\
- \\
- \\
- \\
- \\
- \\
- \\
- \\
-\end{array}$ & $\begin{array}{l}5 \\
2 \\
1 \\
4 \\
1 \\
- \\
1 \\
1 \\
3 \\
1 \\
3 \\
- \\
-\end{array}$ & $\begin{array}{l}- \\
- \\
- \\
- \\
- \\
- \\
- \\
- \\
- \\
- \\
-\end{array}$ \\
\hline Total & 168 & 17 & 24 & 30 & 15 & 25 & 2 & 1 & 32 & 0 & 0 & 22 & 0 \\
\hline \multicolumn{4}{|c|}{ Fracture origins in percent } & 23 & 12 & 20 & 2 & 1 & 25 & 0 & 0 & 17 & 0 \\
\hline
\end{tabular}

aNo fracture "burst" pattern.

bFlaw could not be determined at fracture "burst" origin.

$C_{A}$ narrow subsurface void.

dercentages are based on 127 bars for which fracture origins were identified. 


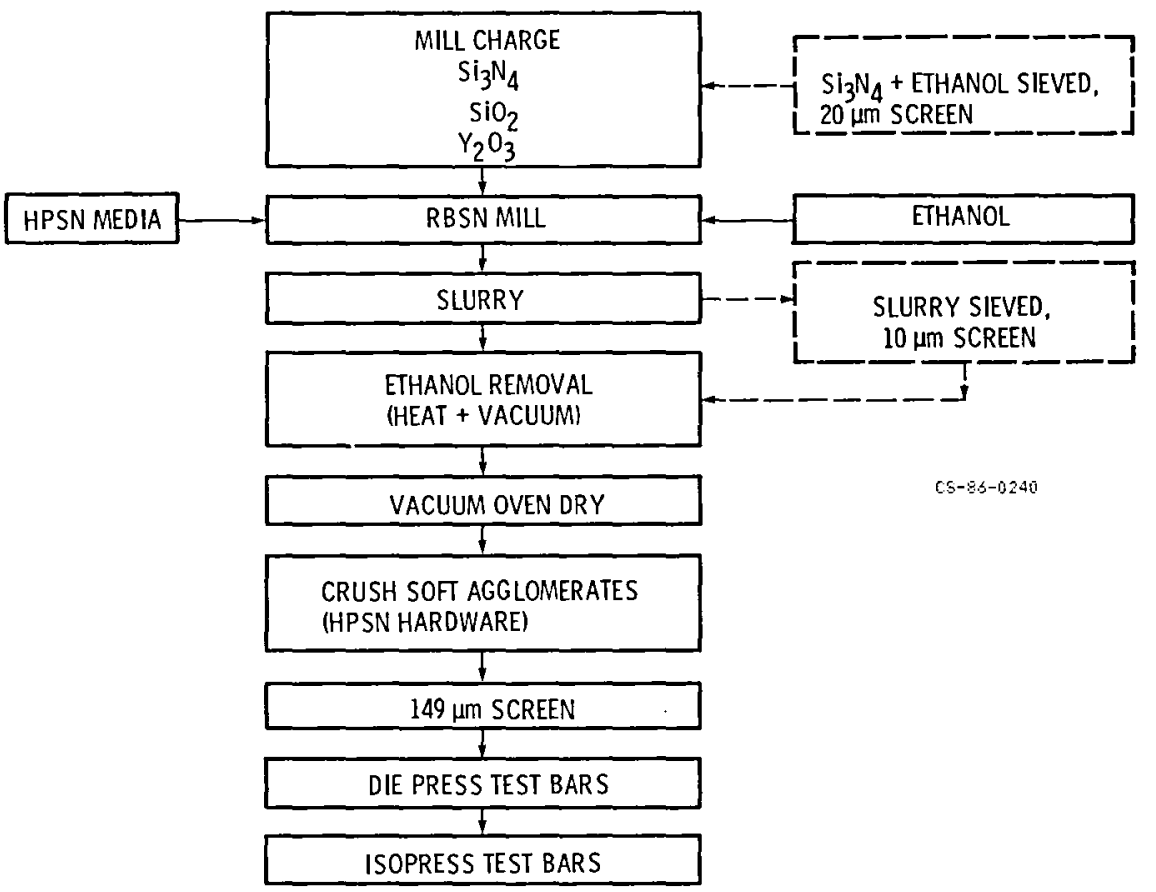

Figure 1. - Powder processing of $\mathrm{Si}_{3} \mathrm{~N}_{4}-\mathrm{SiO}_{2}-\mathrm{Y}_{2} \mathrm{O}_{3}$ composition NASA 6Y.

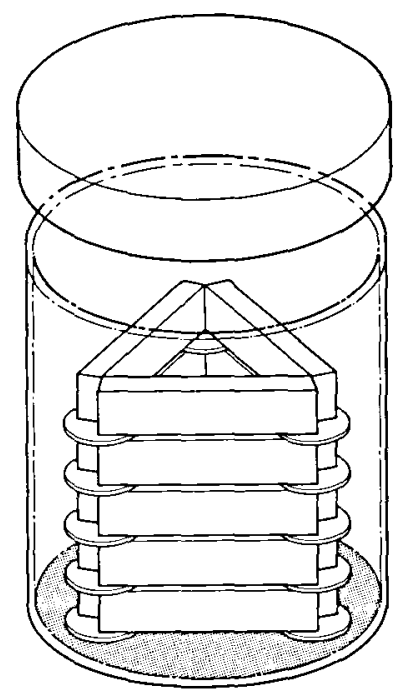

$05-04-0235$

Figure 2. $-\mathrm{Si}_{3} \mathrm{~N}_{4}$ bar/BN setter arrangement in $W$ sinter cup. 


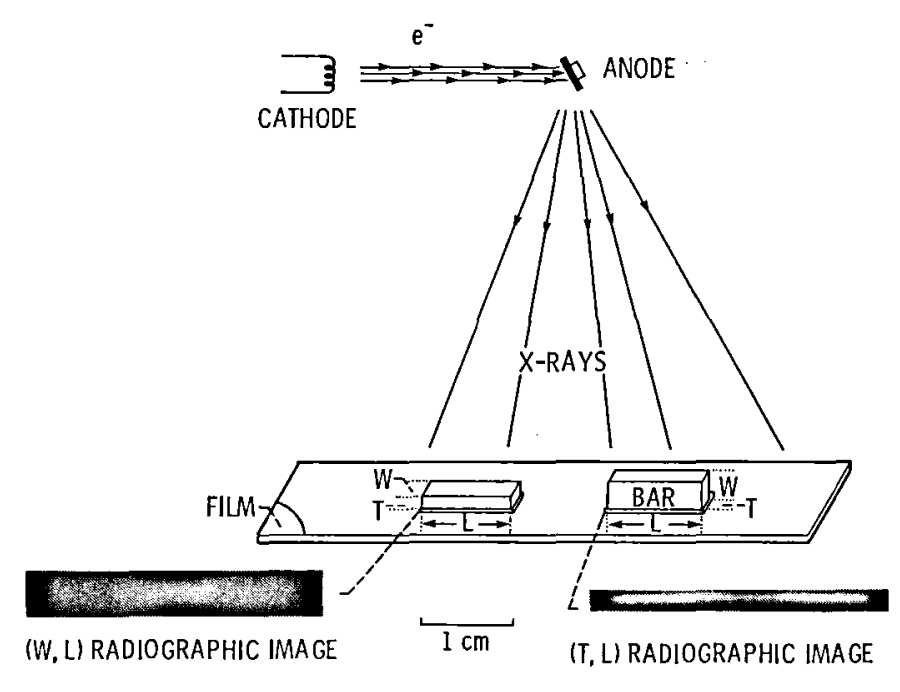

CS-85-4207

Figure 3. - Schematic configuration of conventional radiography employed for characterization of NASA $6 \mathrm{Y} \mathrm{Si}_{3} \mathrm{~N}_{4}$ test bars $(\mathrm{L}=3.0 \mathrm{~cm}, \mathrm{~W}=0.56 \mathrm{~cm}$, $\mathrm{T}=0.28 \mathrm{~cm}$ ). 


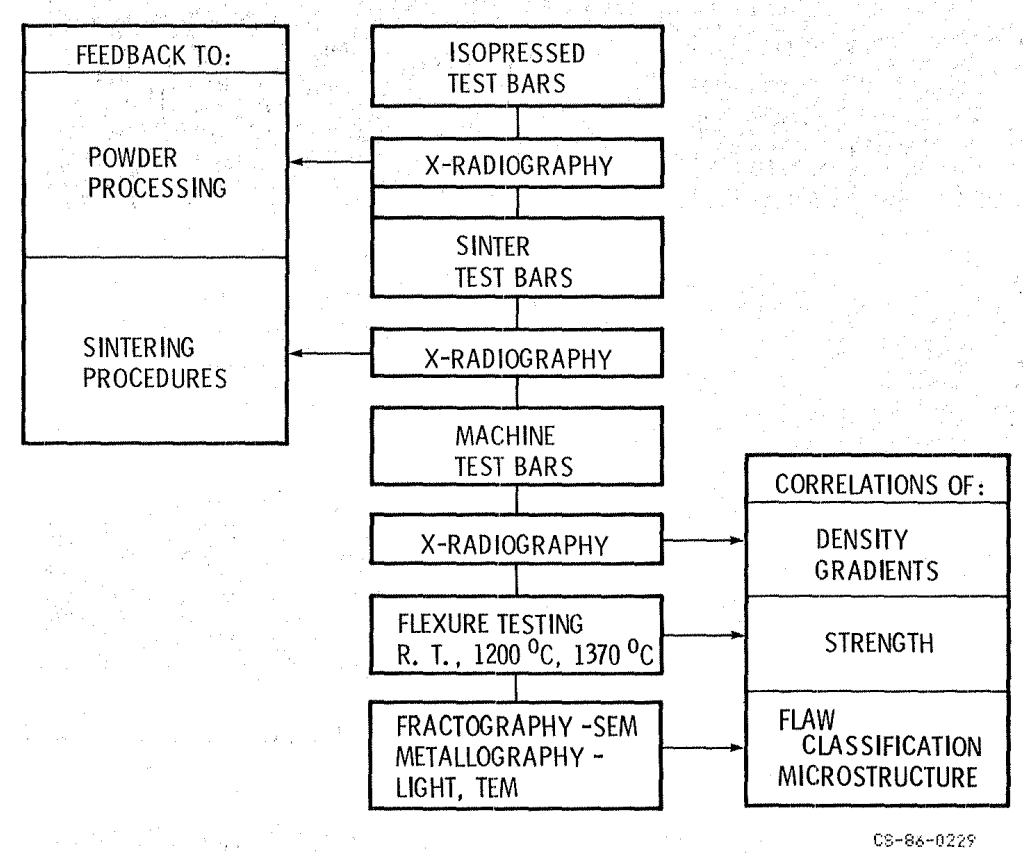

Figure 4. - Characterization, testing, and evaluation of NASA $6 \mathrm{Y} \mathrm{Si}_{3} \mathrm{~N}_{4}$. 

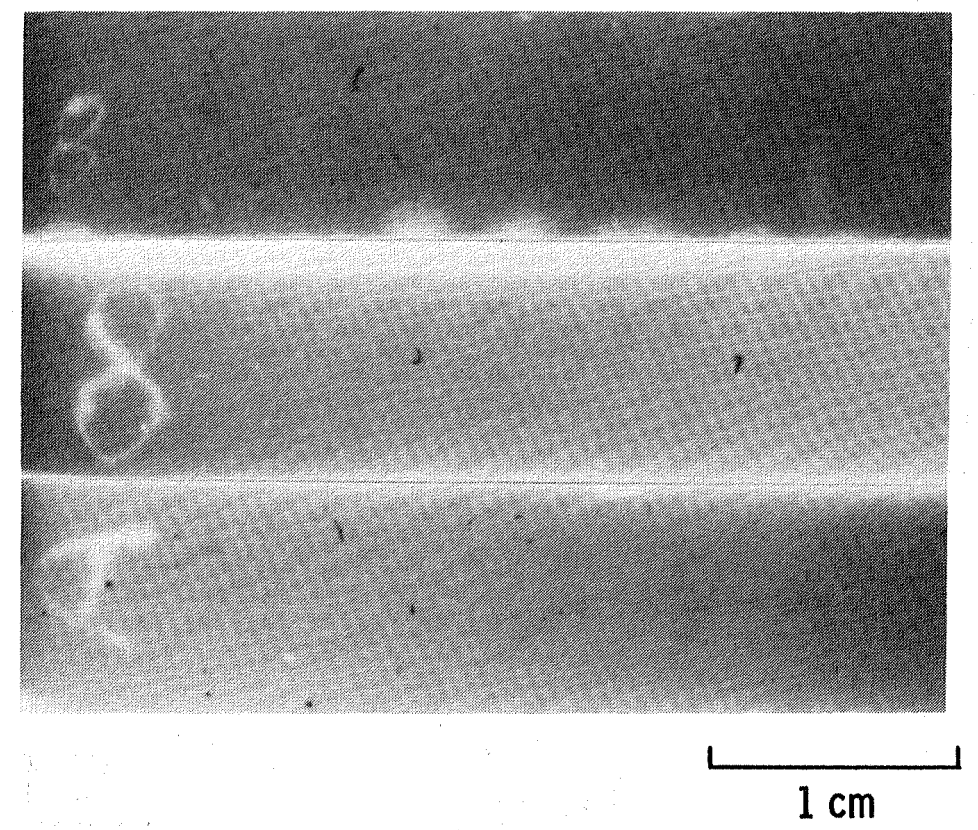

Figure 5. - Radiographs (W, L) of green iso-pressed NASA $6 Y \mathrm{Si}_{3} \mathrm{~N}_{4}$ illustrating absense of dense case/less dense core structure, presense of density/thickness variations, and presence of high density inclusions (dark specks) and low density inclusions or voids. 


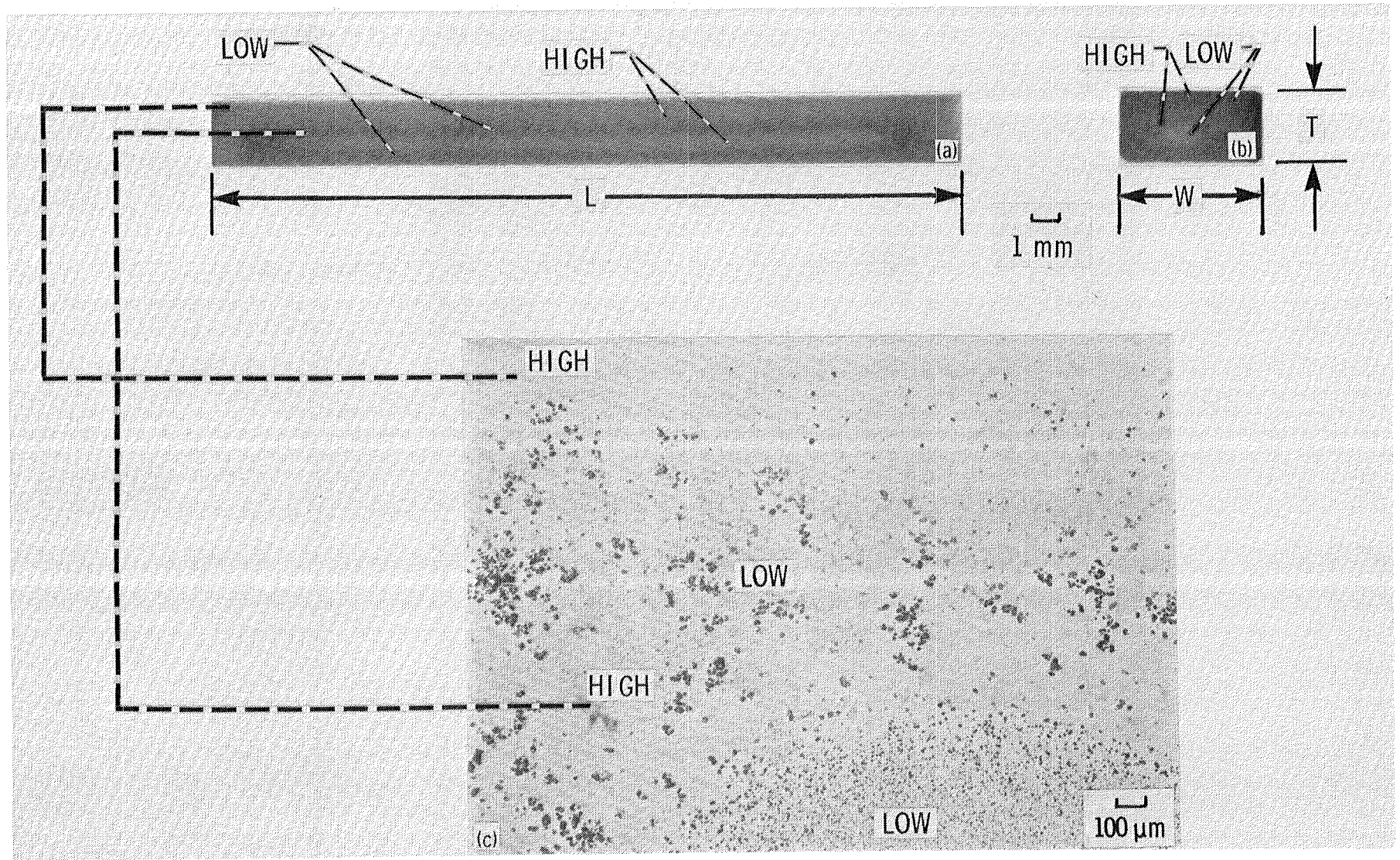

Figure 6. - Sensitivity of radiography to within bar porosity segregation/distribution for NASA $6 \mathrm{Y} \mathrm{Si}_{3} \mathrm{~N}_{4}$ batch 23. (a) Radiograph (T. L); (b) macrostructure (T, W); and (c) microstructure. 

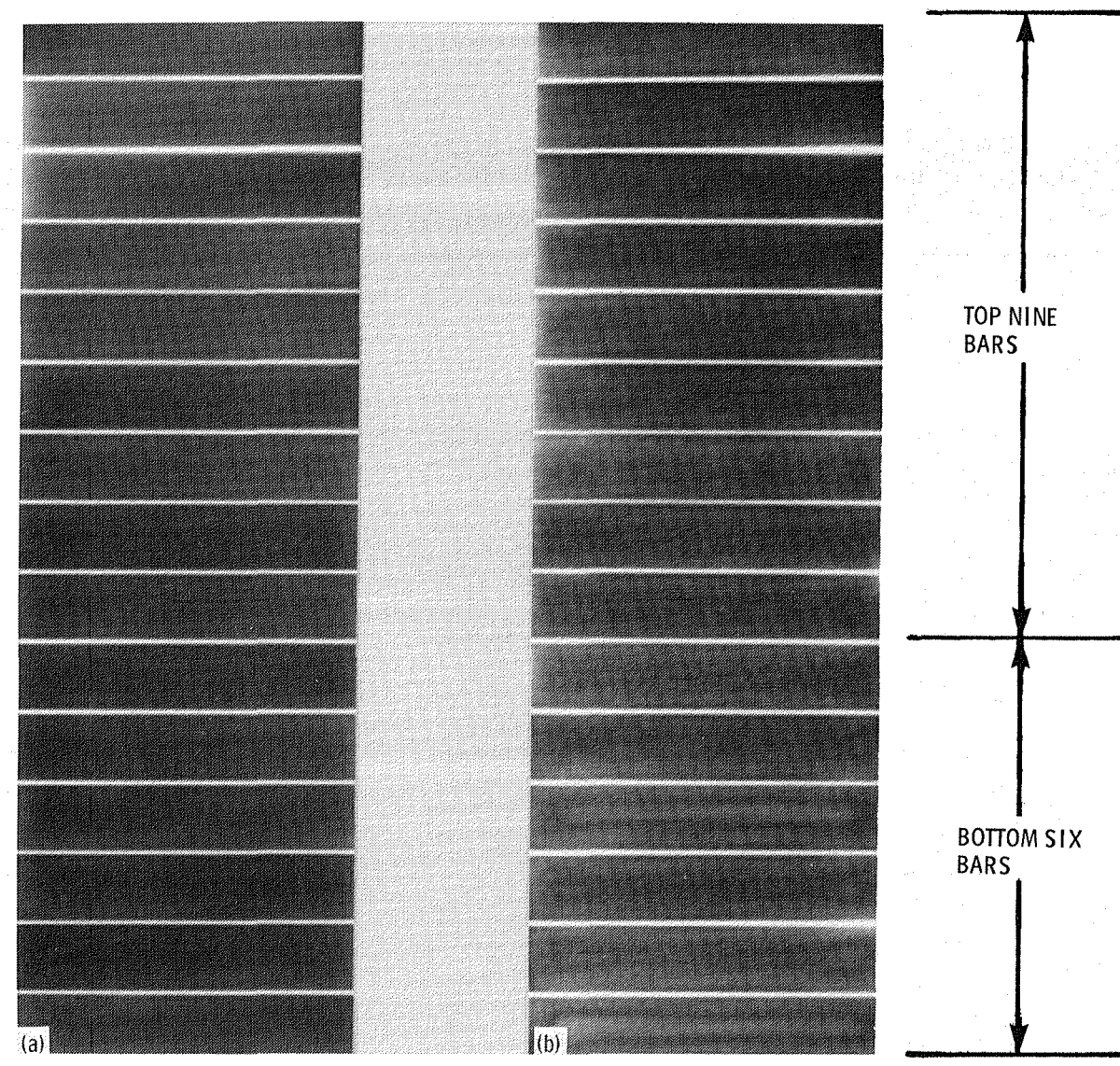

TOP NINE
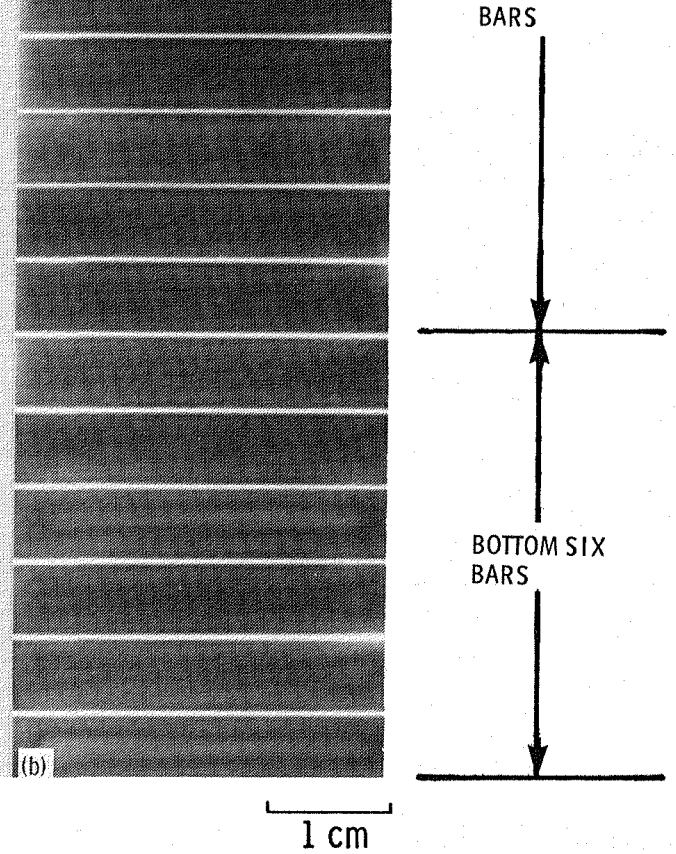

Figure 7. - Radiographs (W, L) of NASA $6 \mathrm{Y} \mathrm{Si}_{3} \mathrm{~N}_{4}$ 15-bar sinter groups illustrating improved top-to-bottom density unifor mity primarily resulting from sinter height adjustment, (a) Batch 28 (sinter height raised $3.8 \mathrm{~cm}$ ), ${ }^{\bar{\sigma}}$ R.T. $=672 \mathrm{MPa}, \mathrm{s}=74 \mathrm{MPa}$; (b) batch 23 (standard sinter height), ${ }^{\sigma}{ }_{\mathrm{R} . \mathrm{T}}=632 \mathrm{MPa}, \mathrm{s}=168 \mathrm{MPa}$. 


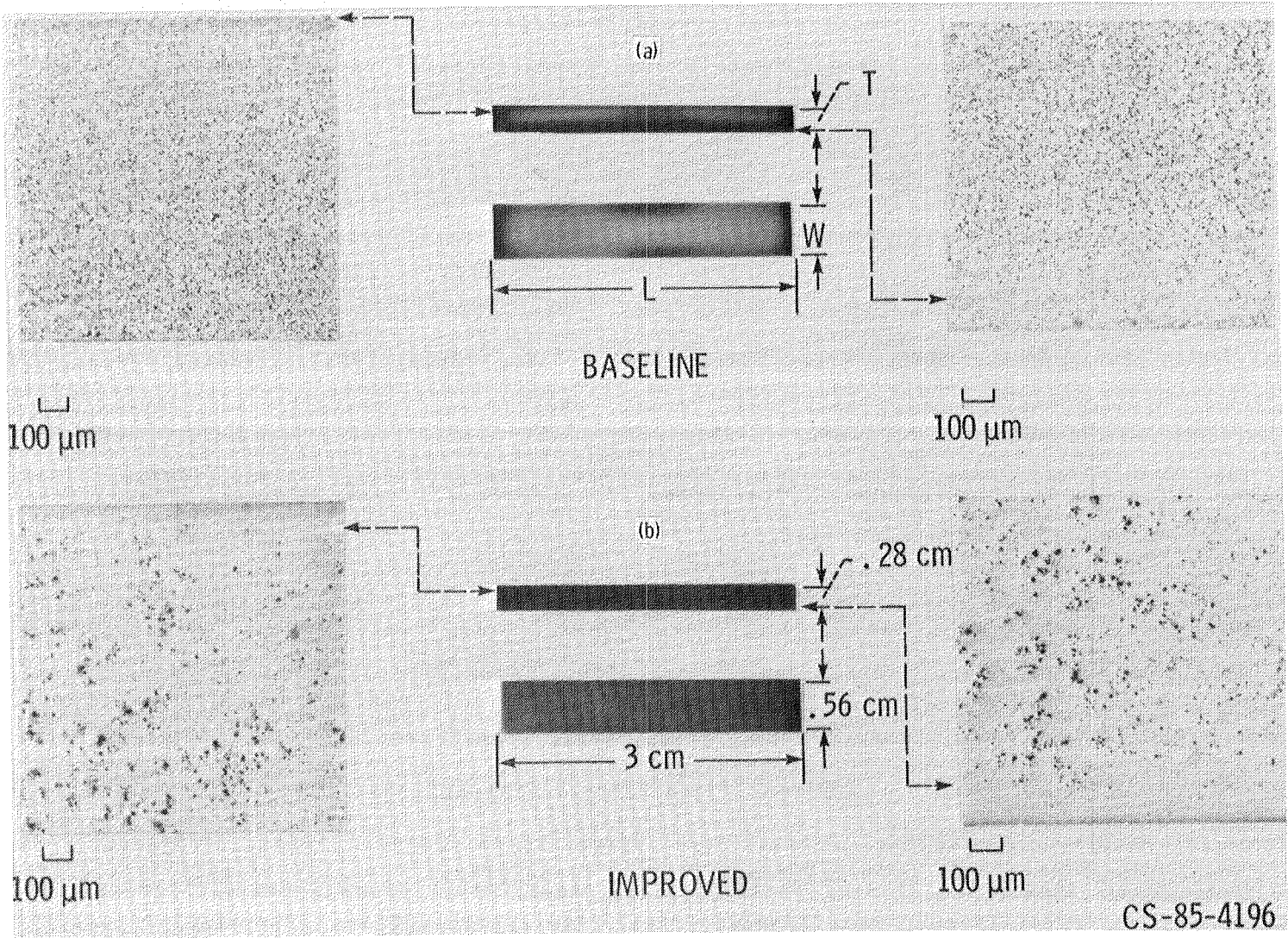

Figure 8. - NASA $6 \mathrm{Y} \mathrm{Si}_{3} \mathrm{~N}_{4}$ radiographs and microstructural comparisons of (a) baseline material versus (b) opti mized material (batch 31), illustrating improved structure. 


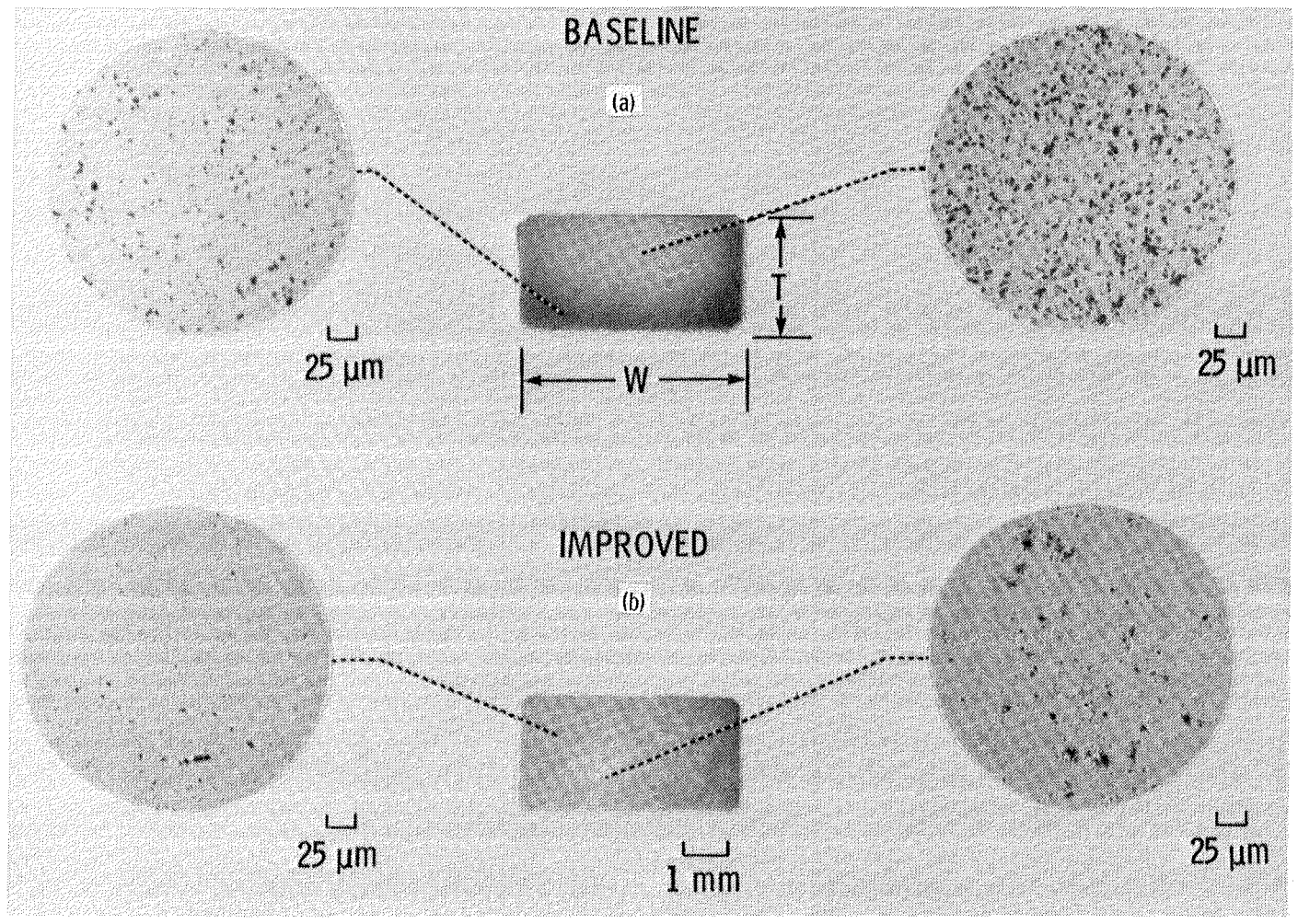

Figure 9. - Microstructures and macrostructures (T, W) of NASA $6 \mathrm{Y} \mathrm{Si} \mathrm{N}_{4}$ illustrating porosity distribution between dense case and less dense core within each sample and between the two samples; and the greatly reduced case-core distinction in the lower sample. (a) Baseline batch, (b) batch 31 with modified processing/sintering procedures. 

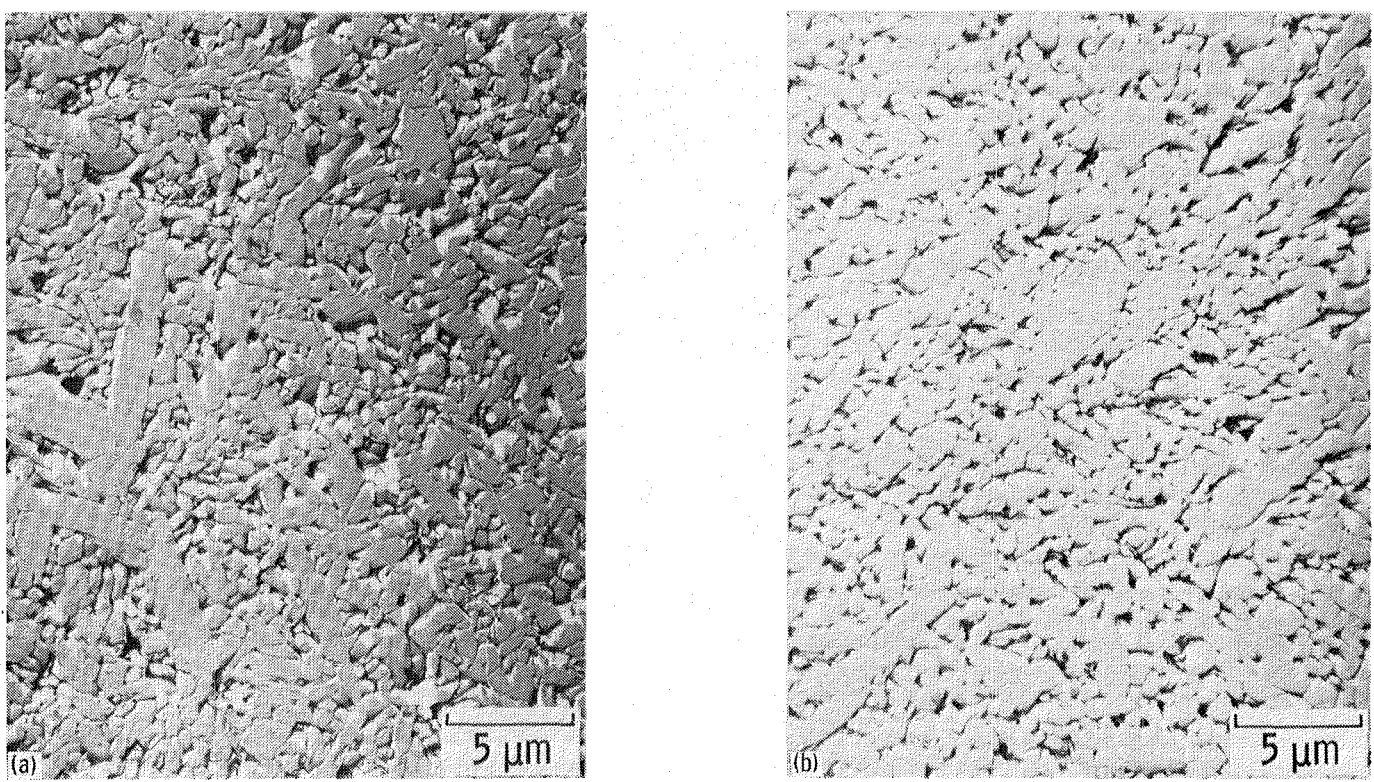

Figure 10. - Transmission electron micrographs of replicas of polished and etched NASA $6 Y S_{3} N_{4}$ batch $23\left(t g=100 \mathrm{~h}, \mathrm{ts}=1.25 \mathrm{~h}, \mathrm{P}_{\mathrm{N}}=5.0 \mathrm{MPa}\right.$, $\mathrm{T}=2140^{\circ} \mathrm{C}$ ) comparing case (a) $\sim 50 \%$ columnar grains, with core $(\mathrm{b}) \sim 20 \%$ columnar grains but larger equiax grains than (a).
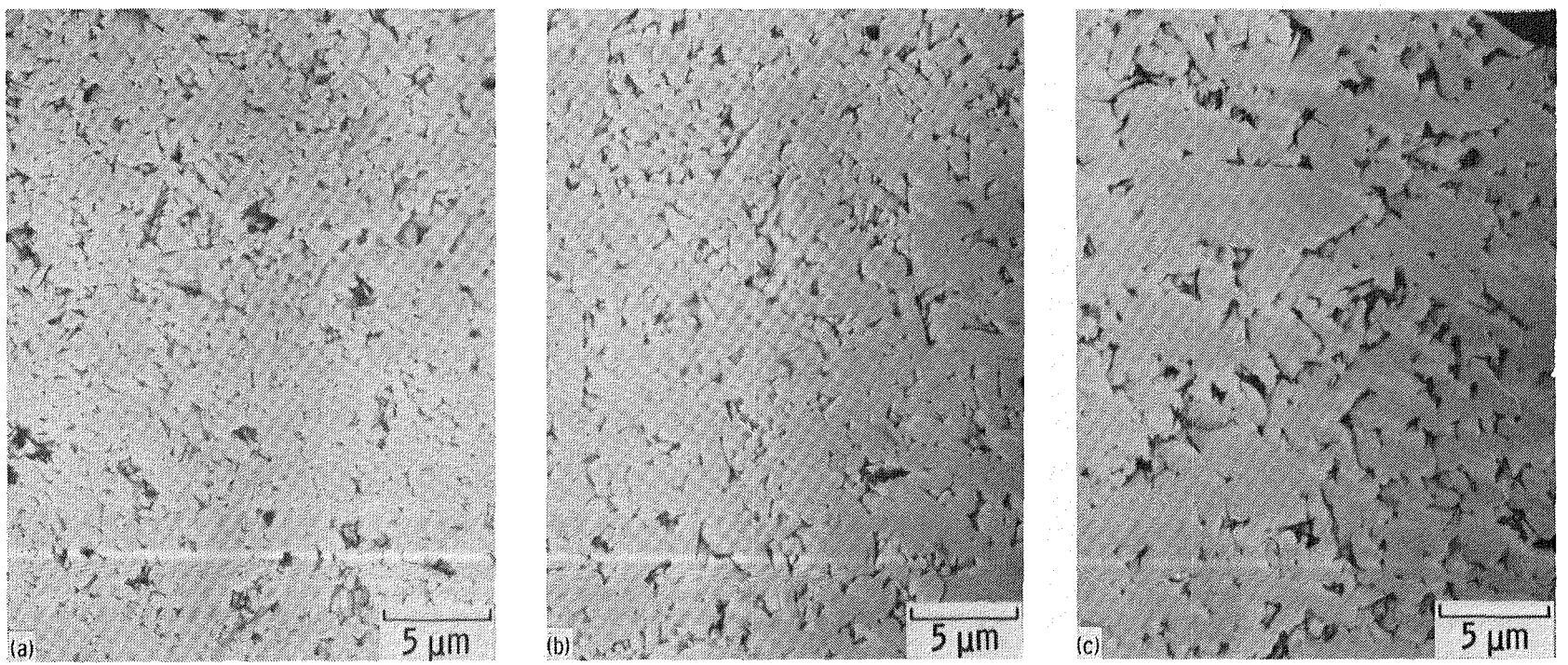

Figure 1l. - Transmission electron micrographs of replicas of pelished and etched NASA $6 \mathrm{Y} \mathrm{Si}_{3} \mathrm{~N}_{4}$ sintered for $2 \mathrm{~h}$ under $5.0 \mathrm{MPa}$ nitrogen pressure illustrating microstructural differences dependent upon sintered temperatures $(a, b)$, and grinding time $(b, c)$. (a) $B$ atch $21, \operatorname{tg}=100 \mathrm{~h}, \mathrm{~T}=2050^{\circ} \mathrm{C}$; (b) batch $20, \operatorname{tg}=100 \mathrm{~h}, \mathrm{~T}=2140^{\circ} \mathrm{C}$; (c) batch $16, \operatorname{tg}=24 \mathrm{~h}, \mathrm{~T}=2140^{\circ} \mathrm{C}$. 

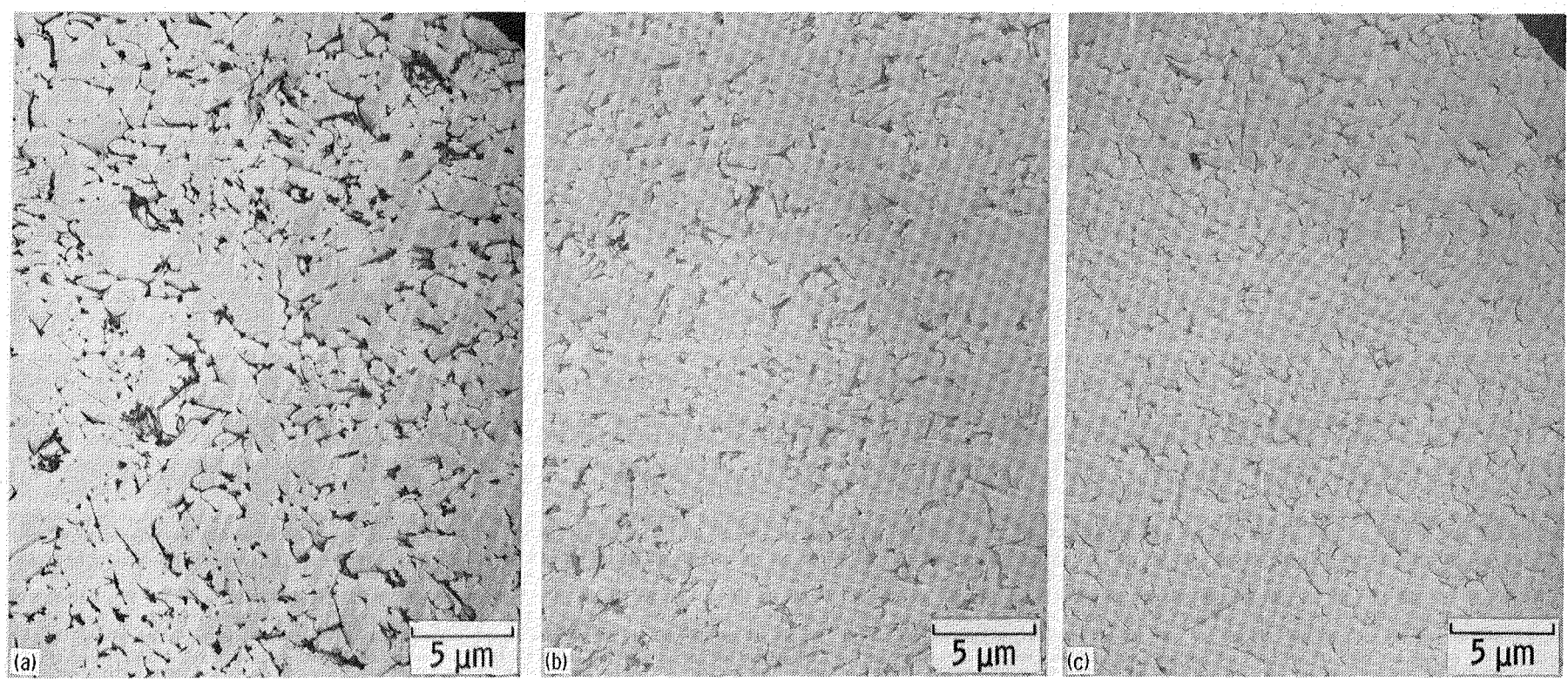

Figure 12. - Transmission electron micrographs of replicas of polished and etched NASA $6 \mathrm{Y} \mathrm{Si}{ }_{3} \mathrm{~N}_{4}$ (ts $=1 \mathrm{~h}, \mathrm{Pn}=2.5 \mathrm{MPa}, \mathrm{T}=21400^{\circ} \mathrm{C}$ ) illustrating influence of powder grinding time (tg) on microstructure. (a) Baseline batch, $\operatorname{tg}=24 \mathrm{~h}\left(\mathrm{BET}=15.3 \mathrm{~m}^{2} \mathrm{gg}\right) ;$ (b) Batch $13, \operatorname{tg}=100 \mathrm{~h}(\mathrm{BET}=24.9 \mathrm{~m} / \mathrm{g}) ;(\mathrm{c})$ batch $14, \operatorname{tg}=$ $300 \mathrm{~h}\left(\mathrm{BET}=37.2 \mathrm{~m}^{2} / \mathrm{g}\right)$. 


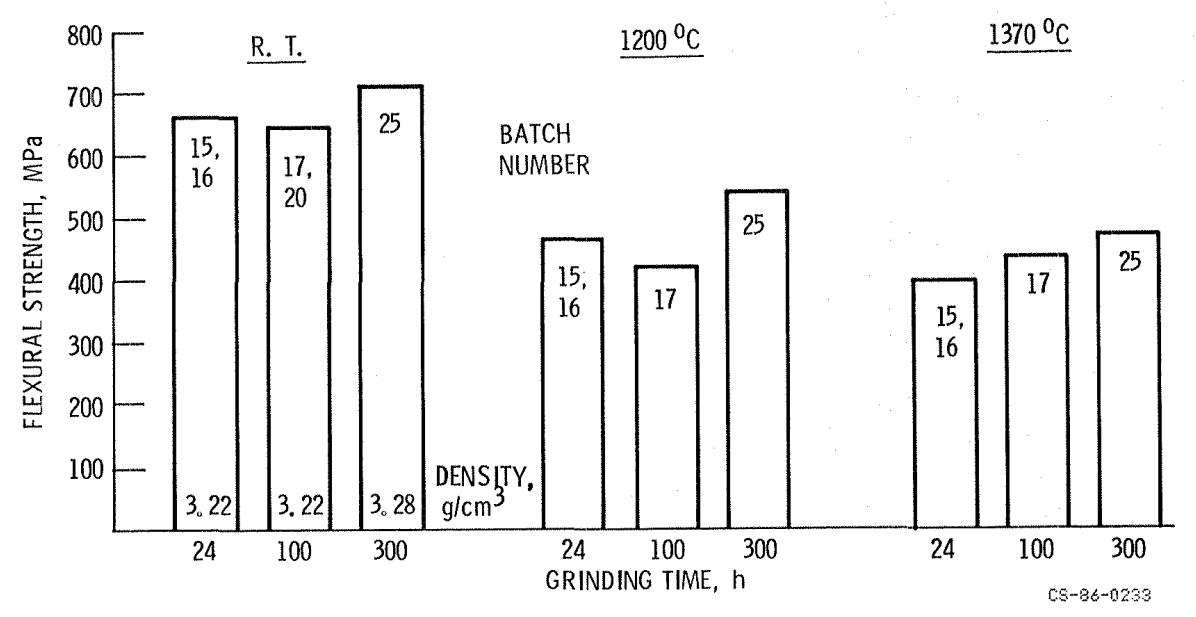

Figure 13. - Effect of grinding time on the flexural strength of NASA $6 \mathrm{Y} \mathrm{Si}_{3} \mathrm{~N}_{4} \mathrm{Ct}_{\mathrm{S}}=2 \mathrm{~h}$, $\mathrm{P}_{\mathrm{N}}=5.0 \mathrm{MPa}, \mathrm{T}=2140^{\circ} \mathrm{C}, \min \mathrm{BN}$ ).

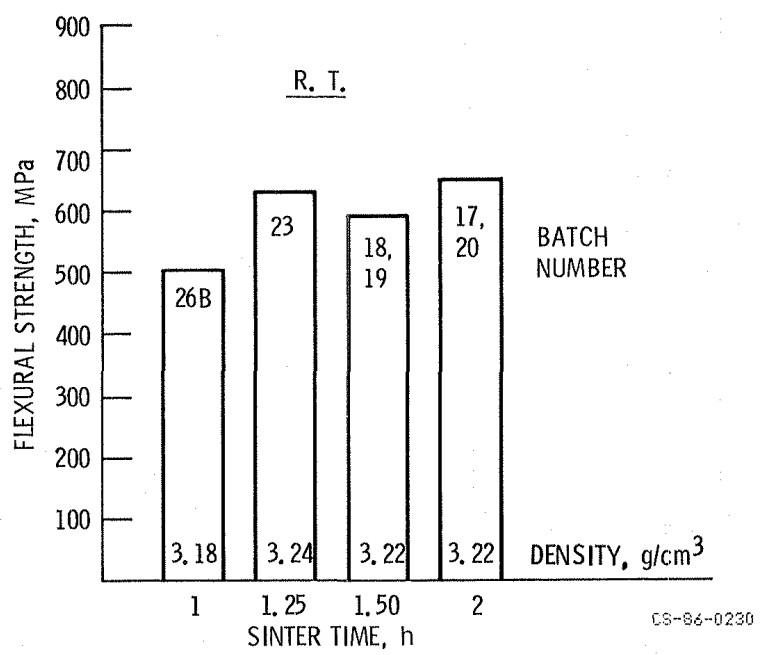

Figure 14. - Effect of sintering time on the flexural strength of NASA $6 Y S_{3} \mathrm{~N}_{4}\left(\mathrm{t}_{\mathrm{g}}=100 \mathrm{~h}, \mathrm{P}_{\mathrm{N}}=5.0 \mathrm{MPa}, \mathrm{T}=2140^{\circ} \mathrm{C}\right.$, $\min B N$ ). 


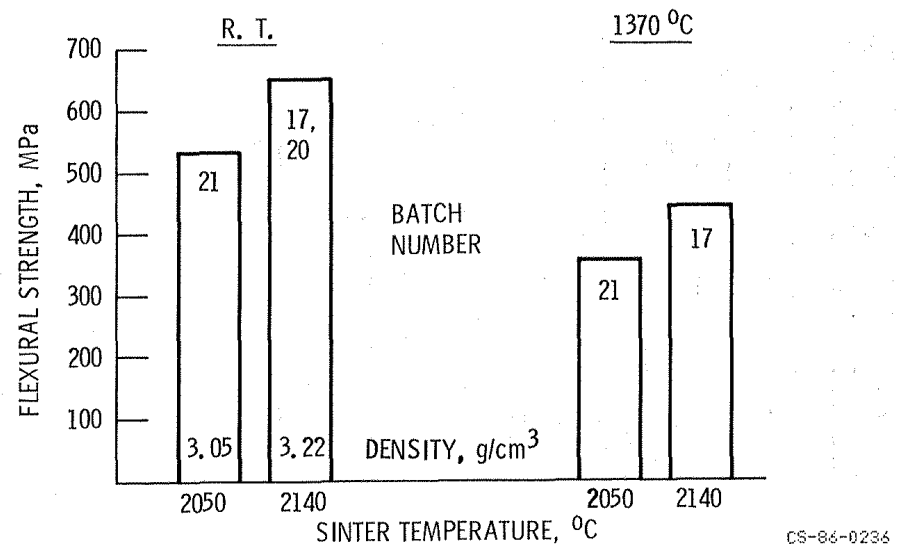

Figure 15. - Effect of sintering temperature on the flexural strength of NASA $6 \mathrm{Y} \mathrm{Si}_{3} \mathrm{~N}_{4}\left(\mathrm{t}_{\mathrm{g}}=100 \mathrm{~h}, \mathrm{t}_{\mathrm{S}}=2 \mathrm{~h}, \mathrm{P}_{\mathrm{N}}=5.0\right.$ $\mathrm{MPa}, \min \mathrm{BN}$ ).

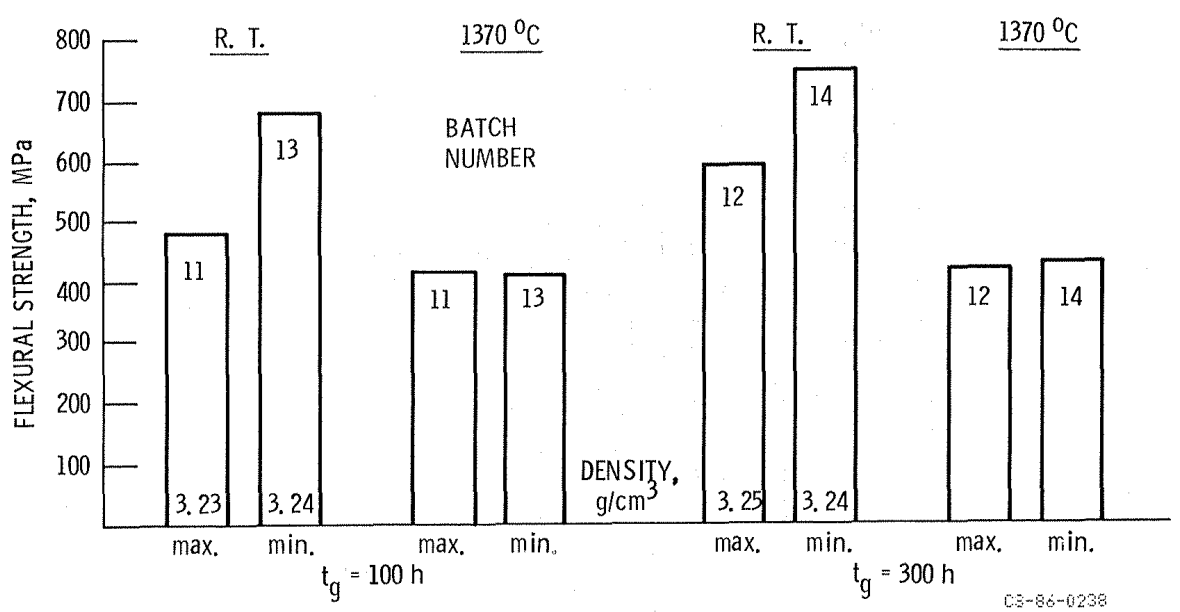

Figure 16. - Effect of BN setter contact on the flexural strength of NASA 6Y $\mathrm{Si}_{3} \mathrm{~N}_{4}\left(\mathrm{t}_{\mathrm{S}}=1 \mathrm{~h}\right.$, $\mathrm{P}_{\mathrm{N}}=2.5 \mathrm{MPa}, \mathrm{T}=2140^{\circ} \mathrm{C}$ ). 


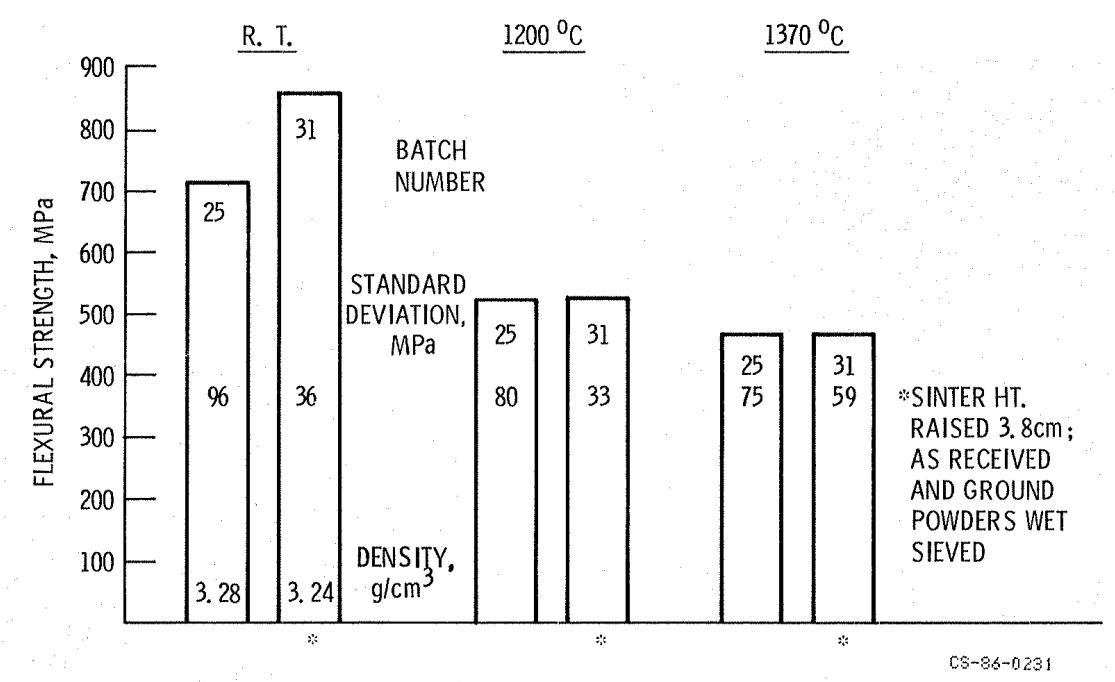

Figure 17. - Effect of sinter height adjustment plus wet sieveing on the flexural strength of NASA 6 Y Si ${ }_{3} \mathrm{~N}_{4}\left(\mathrm{t}_{\mathrm{g}}=300 \mathrm{~h}, \mathrm{t}_{\mathrm{s}}=2 \mathrm{~h}, \mathrm{P}_{\mathrm{N}}=5.0 \mathrm{MPa}, \mathrm{T}=2140^{\circ} \mathrm{C}\right.$, min BN).

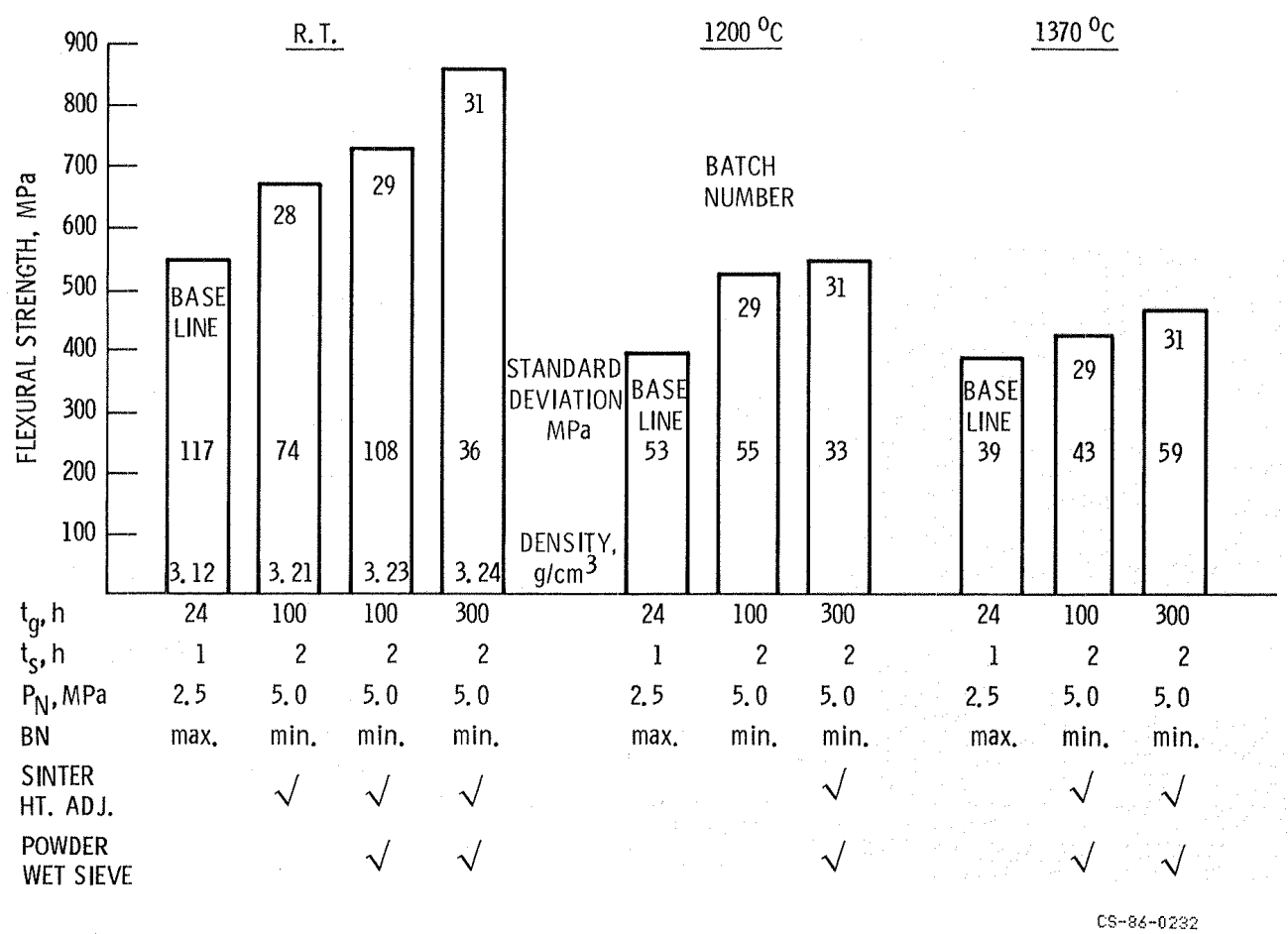

Figure 18. - Effect of modified processing/sintering procedures on the flexural strength of $\mathrm{NASA} 6 \mathrm{Y} \mathrm{Si}_{3} \mathrm{~N}_{4}$ sintered at $2140{ }^{\circ} \mathrm{C}$ 

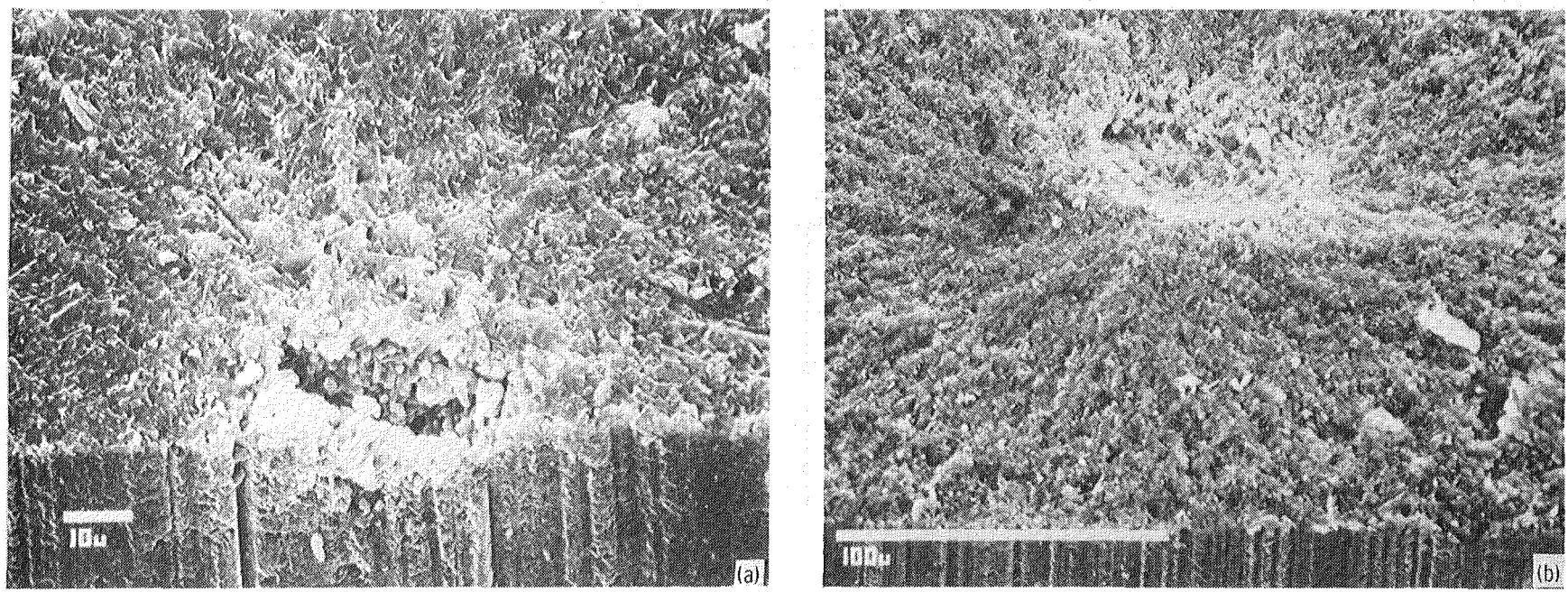

Figure 19. - Scanning electron micrographs of critical flaws in R. T. flexural test failures of NASA $6 \mathrm{Y} \mathrm{Si}_{3} \mathrm{~N}_{4}$. (a) Surface pore, $\sigma_{\mathrm{F}}=620 \mathrm{MPa}$; (b) sub-surface pore, $\sigma_{\mathrm{F}}=645 \mathrm{MPa}$.
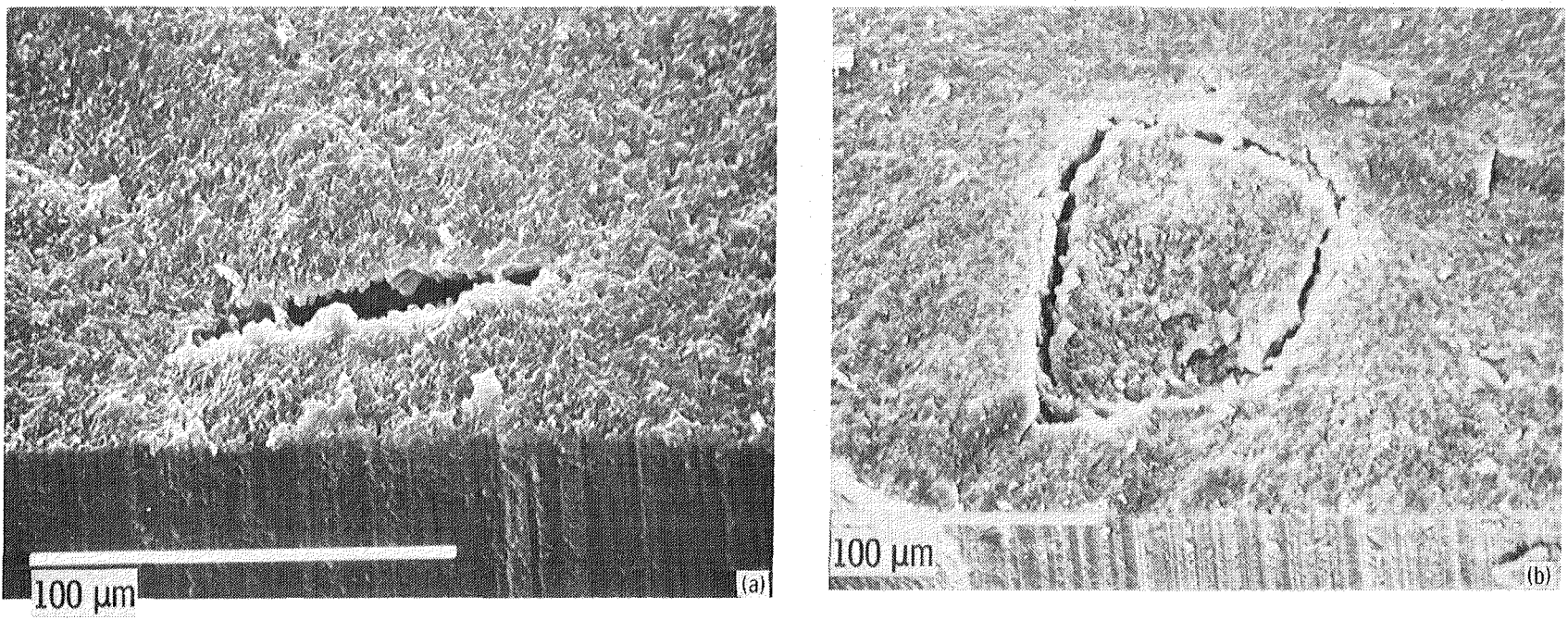

Figure 20. - Scanning electron micrographs of critical flaws in R. T. flexural test failure of NASA $6 \mathrm{Y} \mathrm{Si}_{3} \mathrm{~N}_{4}$. (a) Seam, $\sigma_{\mathrm{F}}=534 \mathrm{MPa}$; (b) Agglomerate, $\sigma_{\mathrm{F}}=$ $470 \mathrm{MPa}$. 

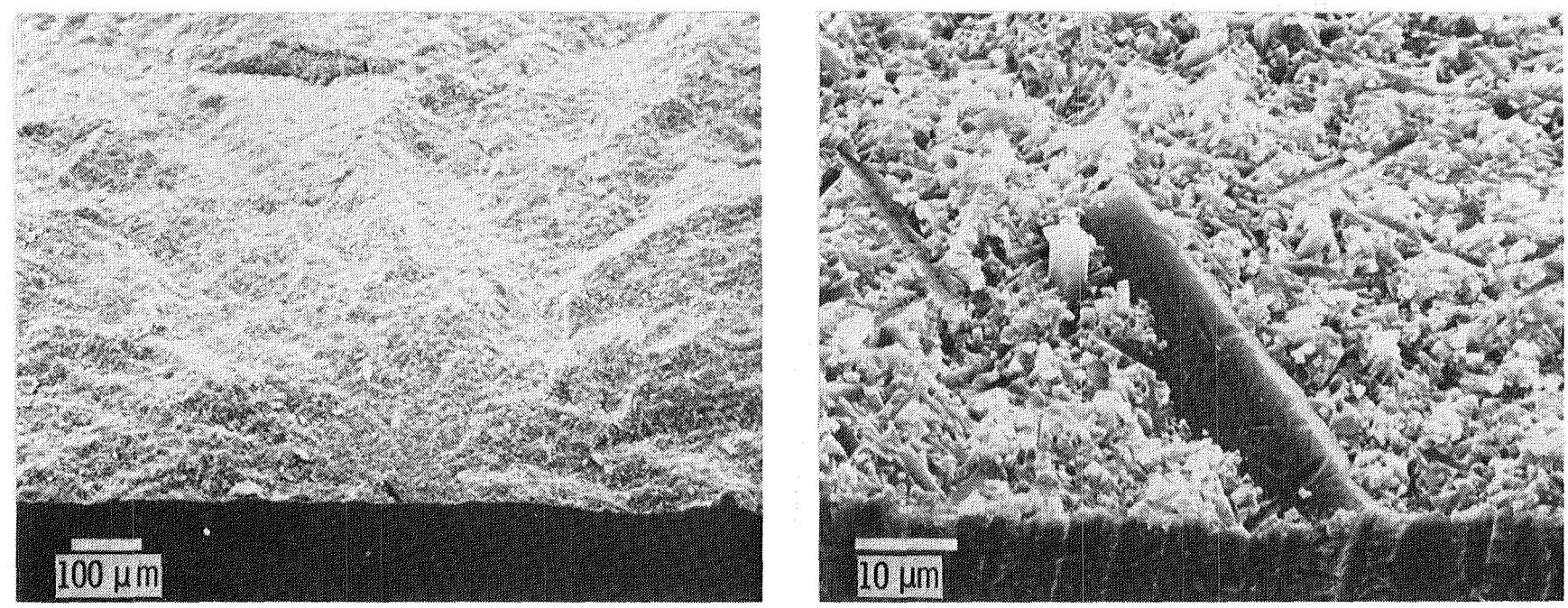

Figure 21. - Scanning electron micrographs of columnar silicon nitride grain at surface of tensile face acting as critical flaw in R. T. flexural test failure at 905 MPa for NASA $6 \mathrm{Y} \mathrm{Si}_{3} \mathrm{~N}_{4}$, batch 31 .
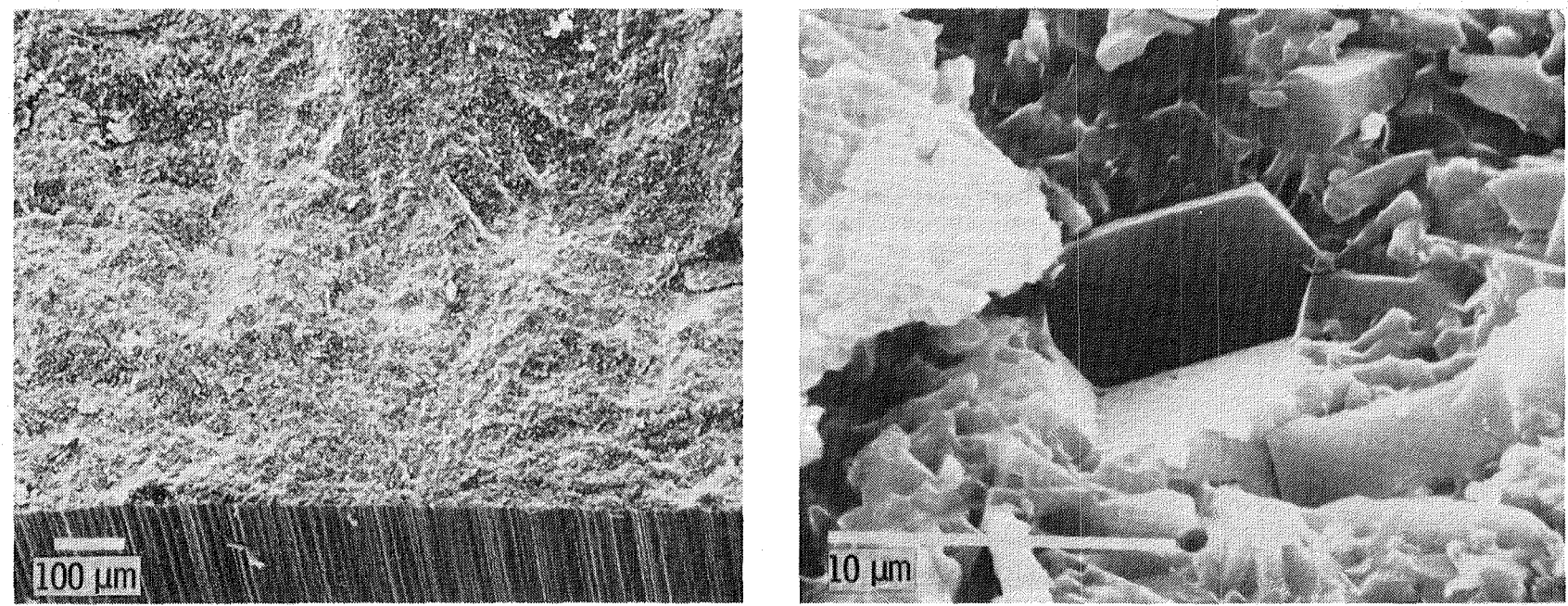

Figure 22. - Scanning electron micrographs of columnar silicon nitride grain below tensile surface which acted as critical flaw responsible for $1200{ }^{\circ} \mathrm{C}$ flexural failure at $535 \mathrm{MPa}$ for $\mathrm{NASA} 6 \mathrm{Y} \mathrm{Si}_{3} \mathrm{~N}_{4}$, batch 31. 

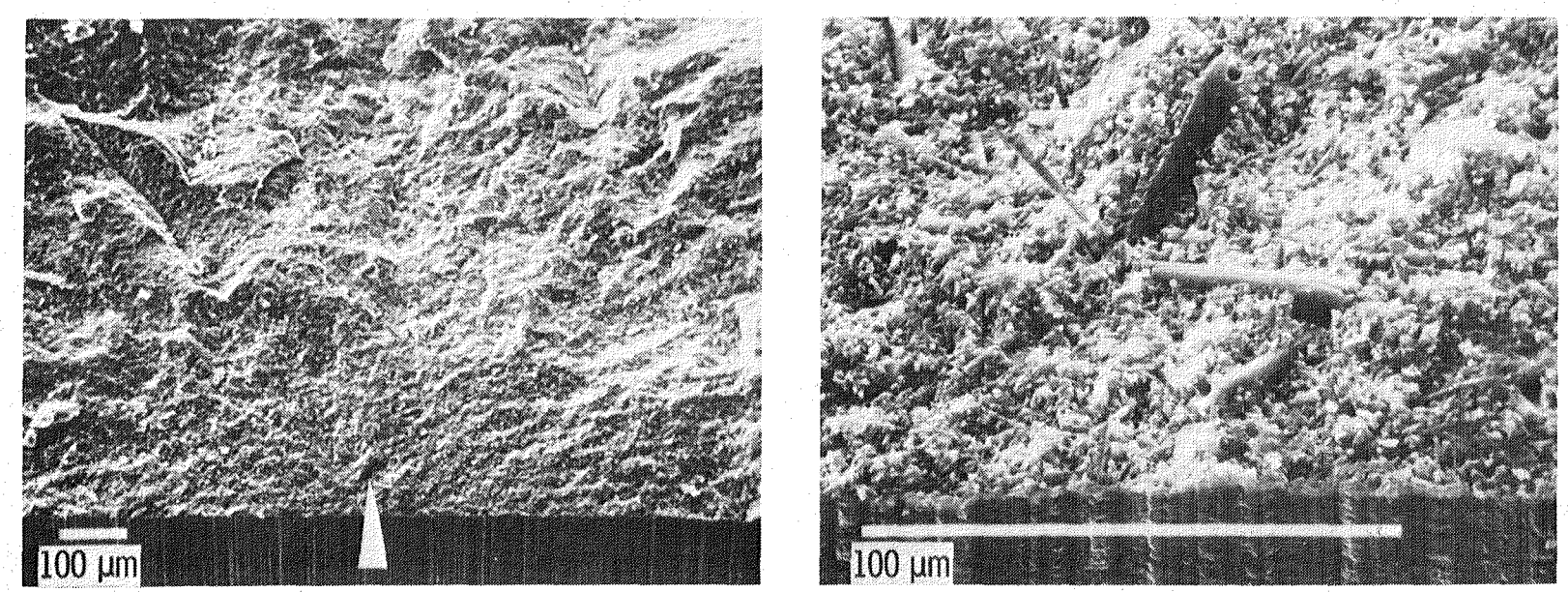

Figure 23. - Scanning electron micrographs of columnar silicon nitride grain cluster below tensile surface which acted as critical flaw responsible for $1370^{\circ} \mathrm{C}$ flexural test failure at $534 \mathrm{MPa}$ for NASA $6 \mathrm{Y} \mathrm{Si} \mathrm{N}_{4}$, batch 31 .
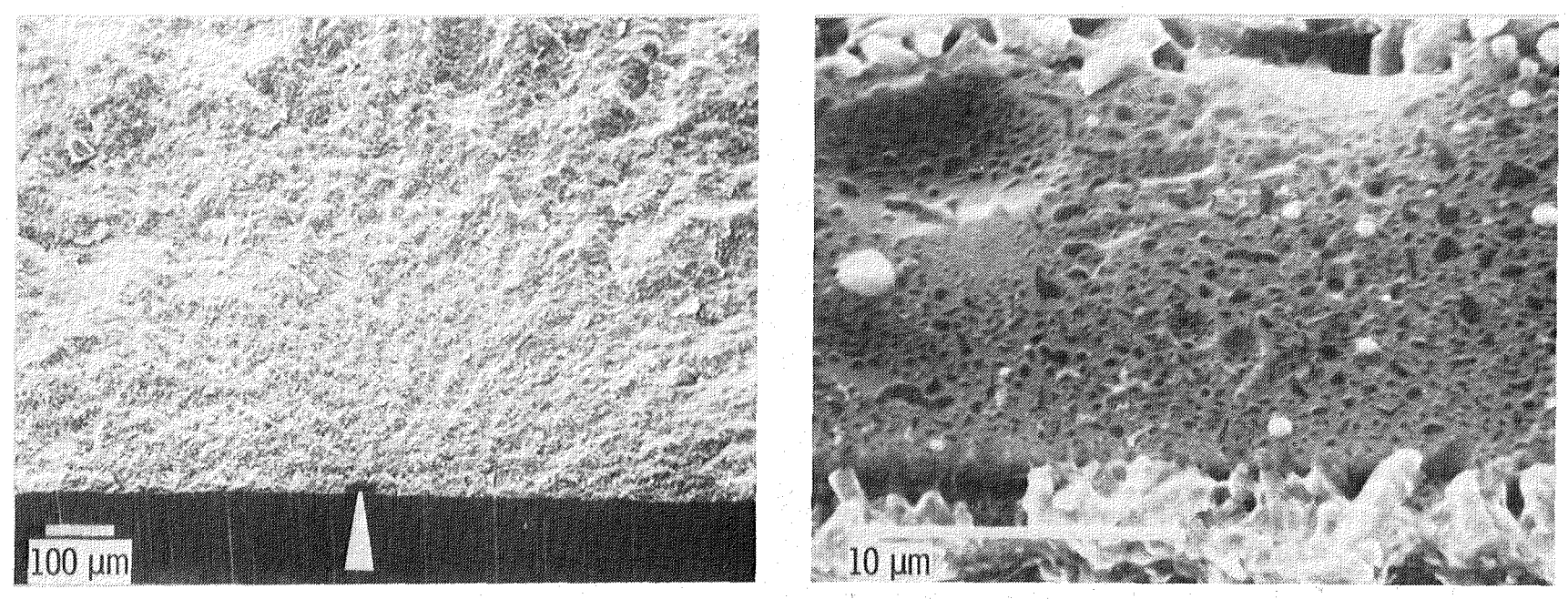

Figure 24. - Scanning electron micrographs of columnar silicon nitride grain at surface of tensile face acting as critical flaw responsible for $1370{ }^{\circ} \mathrm{C}$ flexural failure at $419 \mathrm{MPa}$ for $\mathrm{NASA} 6 \mathrm{Y} \mathrm{Si} 3 \mathrm{~N}_{4}$, batch 31 . 

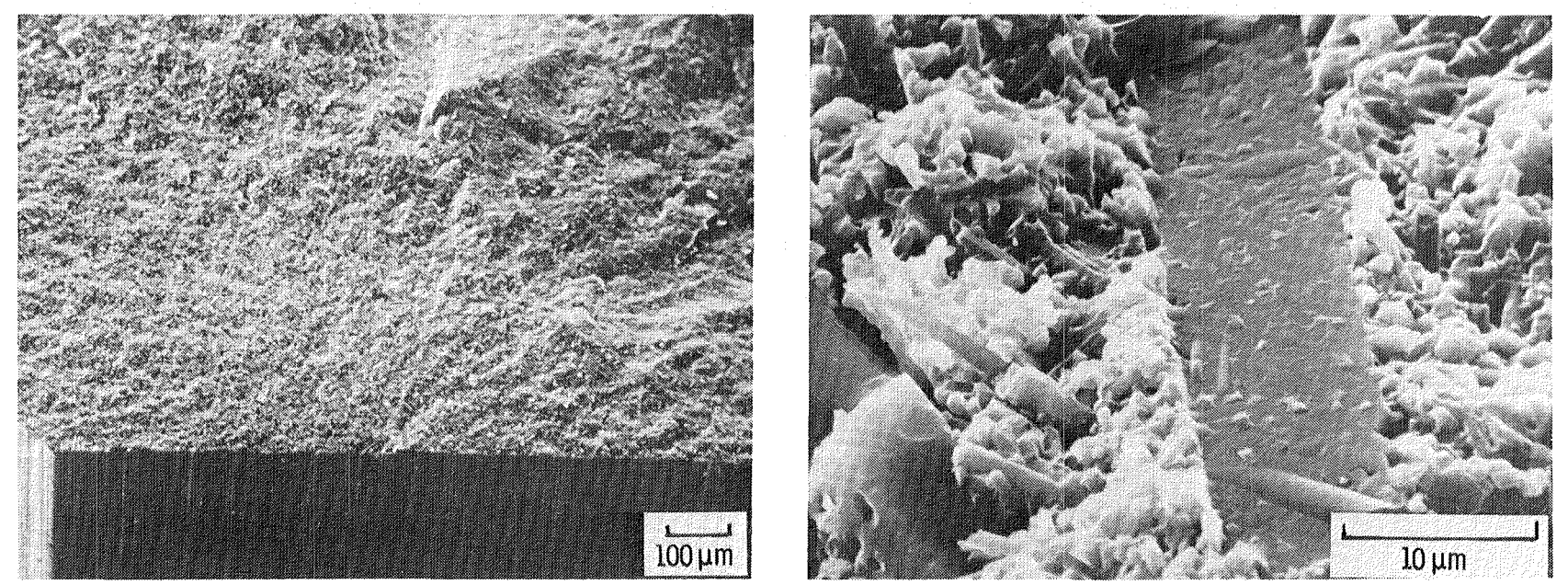

Figure 25. - Scanning electron micrographs of columnar silicon nitride grain planar imprint showing outlining of fine matrix microstructure; $1370{ }^{\circ} \mathrm{C}$ flexural test failure at $430 \mathrm{MPa}$ for NASA $6 Y \mathrm{Si}_{3} \mathrm{~N}_{4}$ batch 31 . 


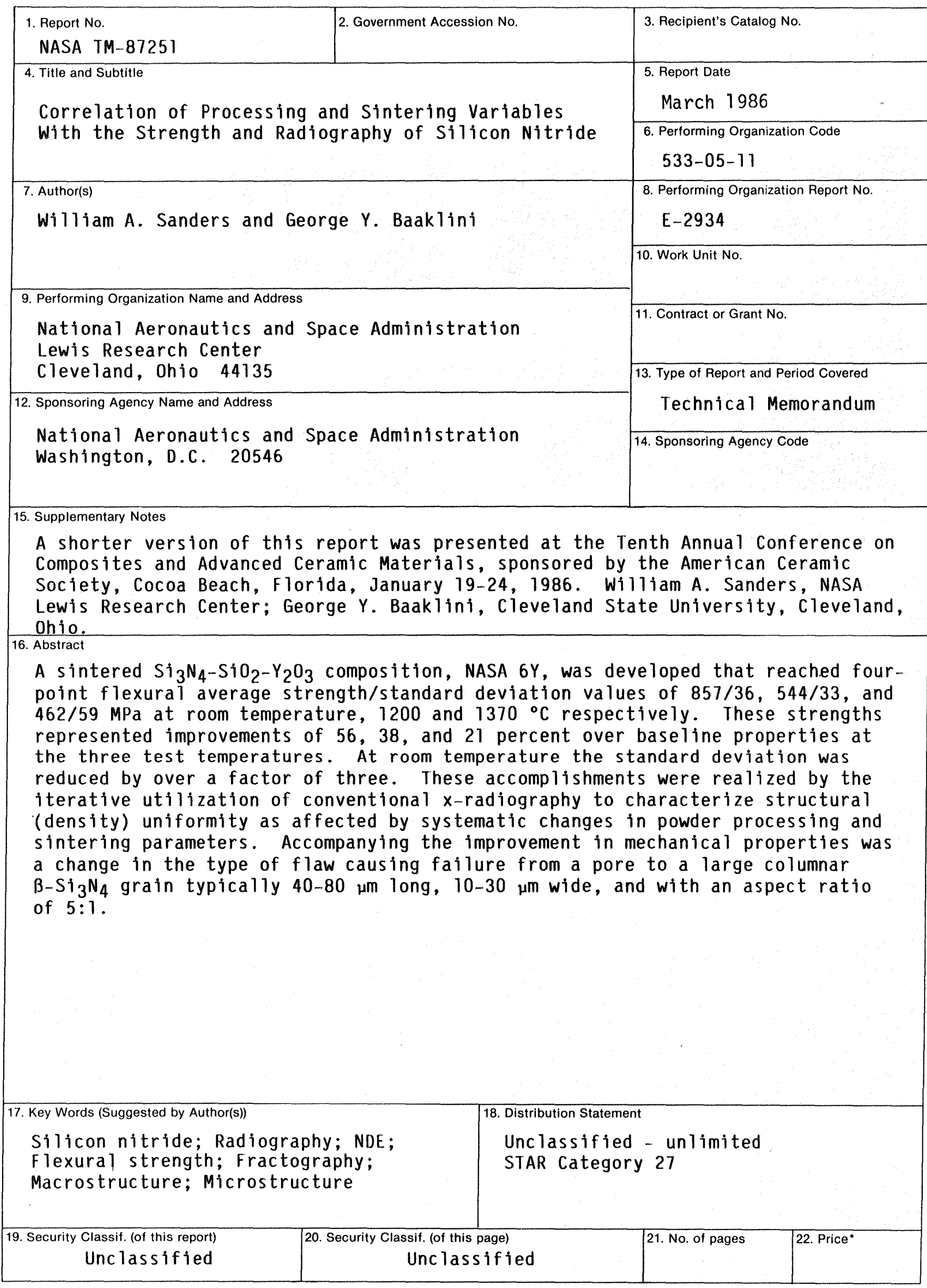

"For sale by the National Technical Information Service, Springfield, Virginia 22161 
End of Document 